NBER WORKING PAPER SERIES

\title{
PERSONNEL MANAGEMENT AND SCHOOL PRODUCTIVITY: EVIDENCE FROM INDIA
}

\author{
Renata Lemos \\ Karthik Muralidharan \\ Daniela Scur \\ Working Paper 28336 \\ http://www.nber.org/papers/w28336 \\ NATIONAL BUREAU OF ECONOMIC RESEARCH \\ 1050 Massachusetts Avenue \\ Cambridge, MA 02138 \\ January 2021, Revised July 2021
}

We thank Nick Bloom, Cesi Cruz, Alex Eble, Deon Filmer, Bob Gibbons, Dan Honig, Julien Labonne, Lant Pritchett, Simon Quinn, Arman Rezaae, Abhijeet Singh, Margaret Stevens, John Van Reenen and several seminar participants at the CSAE, Empirical Management Conference, NEUDC, Oxford, and SIOE for very useful comments and suggestions. We are deeply grateful to M. Srinivasa Rao, B. Srinivasulu, S. Ramamurthy, and staff of the Azim Premji Foundation for their support in setting up and overseeing the data collection that this paper is based on. The views expressed herein are those of the authors and do not necessarily reflect the views of the National Bureau of Economic Research.

NBER working papers are circulated for discussion and comment purposes. They have not been peer-reviewed or been subject to the review by the NBER Board of Directors that accompanies official NBER publications.

(C) 2021 by Renata Lemos, Karthik Muralidharan, and Daniela Scur. All rights reserved. Short sections of text, not to exceed two paragraphs, may be quoted without explicit permission provided that full credit, including $\odot$ notice, is given to the source. 
Personnel Management and School Productivity: Evidence from India

Renata Lemos, Karthik Muralidharan, and Daniela Scur

NBER Working Paper No. 28336

January 2021, Revised July 2021

JEL No. I25,M5,O1

\begin{abstract}
$\underline{\text { ABSTRACT }}$
This paper uses new data to study school management and productivity in India. We report four main results. First, management quality in public schools is low, and $\sim 2 \sigma$ below high-income countries with comparable data. Second, private schools have higher management quality, driven by much stronger people management. Third, people management quality is correlated with both independent measures of teaching practice, as well as school productivity measured by student value added. Fourth, private school teacher pay is positively correlated with teacher effectiveness, and better-managed private schools are more likely to retain their most effective teachers. Neither pattern is seen in public schools.

Renata Lemos

World Bank

1850 I Street NW

Washington, DC 20433

and Center for Economic Performance,

London School of Economics

rlemos@worldbank.org

Karthik Muralidharan Department

of Economics, 0508 University of

California, San Diego 9500 Gilman

Drive

La Jolla, CA 92093-0508

and NBER

kamurali@ucsd.edu

Daniela Scur

Cornell University

Dyson School of Applied Economics

and Management

Ithaca, NY 14853-6201

dscur@cornell.edu
\end{abstract}

A data appendix is available at http://www.nber.org/data-appendix/w28336 


\section{Introduction}

Developing countries have made impressive progress in expanding primary school enrollment in the last couple of decades, but learning outcomes continue to be poor (World Bank; 2018). A growing body of evidence suggests that simply expanding schooling inputs may not be very effective without also improving the productivity of how these inputs are used (Glewwe and Muralidharan; 2016). One possible contributor to school productivity is the quality of its management, and there is growing interest in studying and improving school management. Yet, there is little evidence on the extent to which school management quality is correlated with either teaching practices or school productivity.

In this paper, we examine this question using data from two projects in India, the Development World Management Survey (D-WMS) and the Andhra Pradesh School Choice (APSC) project. The D-WMS is a new measurement tool that we developed for this paper to expand on the original WMS tool (Bloom and Van Reenen; 2007) to obtain comparable but yet more granular measures of management quality in a low-capacity setting. The APSC project studied in Muralidharan and Sundararaman (2015) collected four years of rich panel data on schools, students, and teachers in a representative sample of rural public and private schools in the Indian state of Andhra Pradesh (AP). ${ }^{1}$ The combination of these two datasets allows us to present the first detailed and comparable evidence of the types of management practices used in primary schools in a developing country, across the public and private sector, and also examine how they correlate with measures of school effectiveness.

We report four main results. First, public schools in AP have low management quality. Based on a normalized cross-country comparison, we estimate that management quality in AP public schools is almost $2 \sigma$ below the mean of 6 high-income countries with comparable data. $^{2}$ However, the low management quality in AP is not an outlier after adjusting for log per-capita income. Thus, the income gradient in school management quality across countries could be one reason that education systems in higher income countries add more human capital for each year of schooling, as shown by Schoellman (2011).

Second, within AP, private schools are much better managed with an average management score that is $1.36 \sigma$ higher than in AP public schools (normalized relative to the distribution of AP public schools). Our management score can be decomposed into scores

\footnotetext{
${ }^{1}$ The original state of AP was divided into two states (AP and Telangana) on June 2, 2014. Since this division took place after our data collection, we use the term "AP" to represent the original undivided state.

${ }^{2}$ School management scores for other countries were collected as part of Bloom et al. (2015), and are comparable with the AP data because they were collected based on the same measurement scale. We include only public schools from the WMS dataset in this exercise. The figure normalizes management scores across countries since it makes cross-country comparisons.
} 
on both operations and people management, and we see that the public school disadvantage is driven primarily by very low scores on people management: private schools scored nearly $4.8 \sigma$ higher than public schools on this index. Relative to global benchmarks, the comparable scores for AP private schools are in line with those of public school systems in Brazil, Italy, and Colombia. This suggests that the private sector in India is able to achieve measures of management quality comparable to public school systems in much richer countries.

Third, we find that school management quality (and especially people management) is significantly correlated with independent measures of teaching quality as well as student value-added. In public schools, a $1 \sigma$ higher people-management score is associated with $0.26 \sigma$ better teacher practices and $0.34 \sigma$ higher student value added. In private schools, these are $0.24 \sigma$ and $0.16 \sigma$ respectively. We also find that a large portion of the differences in value-addition across public and private schools can be explained by differences in the quality of people management (in an accounting sense, but not necessarily in a causal sense).

Fourth, we find that better management is directly correlated with personnel policies that reward effective teaching on both the intensive (wage) and extensive (selection) margins. In private schools, more effective teachers, measured by teacher value-added (TVA), receive significantly higher wages even after controlling for observable teacher characteristics. A teacher who adds an extra $1 \sigma$ to student learning each year on average is paid about $26 \%$ higher wages. We find no correlation between TVA and wages in public schools. Better managed private schools are also more effective at selecting and retaining their most effective teachers, but we find no such relationship in public schools.

A key question for interpreting our results is to understand where the variation in management practices comes from and what it is correlated with. We examine correlations of management practices with school, teacher, and head-teacher characteristics and do find some meaningful relationships - especially with parental education and employment, and teacher qualifications and school size in private schools. However, we still find considerable variation in management quality after controlling for all these characteristics, and all the results above hold even with the residualized measure of management quality.

This residual variation most likely reflects idiosyncratic variation in school-level management practices. This is consistent with the management scores in our setting being below 2.5 for most schools on the D-WMS scale, which codes management quality on a 1-5 scale. On this scale, scores below 3 reflect variation in individual practices that are not formally codified in any school management policy. As such, the variation in management quality in our data is best interpreted as reflecting variation in management practices employed by individual school leaders rather than variation in formal policies. 
Our first contribution is to the measurement of management practices in low and middle income countries (LMICs). Specifically, this paper presents the development and first use of the enhanced measurement tool (the D-WMS) designed for low-capacity contexts. The survey instruments along with detailed notes on administering and coding the surveys are included in Appendix B. ${ }^{3}$ We recommend the use of these tools for future research on management in LMICs (wherever feasible) for three reasons. First, it allows for a more precise and granular understanding of management practices and their relationship with productivity - especially in the lower end of the distribution where management practices in LMICs are concentrated. ${ }^{4}$ Second, the greater precision in measurement will improve power for detecting changes in management quality in response to interventions to improve management. ${ }^{5}$ Third, the D-WMS maintains comparability with the original WMS that has been deployed in several settings and allows cross-country comparisons of the sort shown in this paper. ${ }^{6}$

Second, we show that management quality - especially the quality of personnel management - is strongly correlated with school productivity. Prior work has documented the correlation between school management quality and levels of test scores across secondary schools in (primarily) OECD countries (Bloom et al.; 2015). However, differences in testscore levels across schools could reflect omitted variables such as student selectivity and may not be a good measure of school productivity. The combination of independent measures of teaching practices and panel data on student learning allow us to present direct evidence on the correlation between school management quality and independent measures of school effectiveness and productivity. ${ }^{7}$

Third, we complement the literature on school leadership where multiple papers have studied the impact of changes in principals and superintendents on school quality, and shown that school leaders "matter" (Coelli and Green; 2012; Walsh and Dotter; 2020; Lavy and

\footnotetext{
${ }^{3}$ All survey materials are available on the WMS website: www.worldmanagementsurvey.org

${ }^{4}$ For instance, using the WMS comparable scores, $81 \%$ of the public schools in AP would have a peoplemanagement score of 1 , which is the lowest possible score and would generate considerable floor effects in measurement. With the D-WMS scoring grid, only $6 \%$ of schools scored the minimum score of 1 .

${ }^{5}$ For instance, using the WMS scales to study the relationship between management quality and school productivity in our setting would have yielded directionally similar findings, but with larger standard errors and more insignificant results due to the greater coarseness of the coding relative to the D-WMS.

${ }^{6}$ Since the time we developed, piloted, refined, and finalized the D-WMS tool for this project, we have shared the D-WMS instrument and methodology with research teams in Brazil, Colombia, Haiti, Indonesia, Mexico, Mozambique, Pakistan, Tanzania and Puerto Rico.

${ }^{7}$ Several studies have found that estimates of the impact of education interventions using value-added methods that control for lagged test scores are comparable to those obtained from experimental studies. (e.g., Kane and Staiger; 2008; Kane et al.; 2014; Chetty et al.; 2014). Prior work in developing countries has documented the correlation between intermediate outcomes of management quality (such as teacher absence or time-on-task) and value-added (e.g., Duflo et al.; 2012; Romero et al.; 2020), but has not directly measured management practices or correlated them with school productivity.
} 
Boiko; 2017; Munoz and Prem; 2020). Yet, for the most part, this literature has not consistently measured specific practices of school leaders. Our results showing that variation in management practices measured by the D-WMS are also correlated with independent measures of teacher value-added and practices suggest that differences in school productivity that may otherwise be attributed to school "leadership" can be accounted for by specific management practices. This knowledge may help in designing programs whereby school leaders could be coached to implement better practices and become more effective, as shown in the United States (Fryer; 2014, 2017). In contrast, the main practical implication of simply knowing that school leaders "matter" would be to focus on the selection margin of identifying effective school leaders.

Finally, we contribute to the broader literature on public-sector personnel economics (e.g. Lazear (1995); Finan et al. (2015)), and to the comparative analysis of management in the public and private sector (Rainey and Chun; 2007). Specifically, we present (to our knowledge) the first evidence that combines measures of management quality, employee behaviors, and productivity; with comparable data across public and private sector entities in any sector. This allows us to demonstrate the central role played by better personnel management in explaining the greater productivity in the private sector.

\section{The Indian primary school institutional context}

The undivided state of Andhra Pradesh (AP) would be India's fifth largest state, with a population of 85 million. At the time of this study, AP had similar averages to the rest of India on measures of human development, primary school enrolment, literacy, infant mortality and teacher absence (Muralidharan and Sundararaman; 2011). In this context,

public schools are owned and run by the government, and private schools are owned and run by private individuals or organizations (including religious and charitable ones). At the time of the study, an estimated 3.2 million children in AP attended public schools and 2.1 million attended private schools (see Young Lives dataset in Woldehanna et al. (2018)).

The private schools in our study sample are not elite schools. Rather, they represent a segment of schools that are referred to as "low-cost" or "budget" private schools. These lowcost private schools have substantially lower per-student expenditure than public schools, and the vast majority of enrollment in private schools in India is accounted for by this segment of schools (CSF; 2020). Similar trends are seen in Pakistan (Andrabi et al.; 2008). The main driver of the lower costs in these private schools is that they pay much lower teacher salaries. 
Public school teachers are much more likely to have formal teacher training credentials (99\% vs. 34\%), though these qualifications have been shown to be poor predictors of better student performance (Muralidharan and Sundararaman; 2011). They are civil servants hired by the state government on permanent contracts and are paid over 5 times the average private school teacher salary (Rs. 14,286 vs. 2,607 per month in data collected between 2008-2012). Decisions regarding teacher postings and transfers are typically made at the district level. While this process is often politically influenced in several Indian states,(Béteille; 2009) Andhra Pradesh had introduced a systematic and transparent process of teacher postings and transfers since the late 1990s (Ramachandran et al.; 2016). ${ }^{8}$

Teacher effort and accountability are significantly higher in private schools. Private schools have much lower rates of teacher absence (9\% vs. 24\%), and higher rates of observed active teaching when measured by unannounced visits to schools (50\% vs. $35 \%$ ). They also have a longer school year (11 more working days) and longer school days (45 minutes longer per day). Public primary schools in our sample have an average of 68 students and 3 teachers across grades 1-5. Private schools are substantially larger with over 300 students on average and about 14 teachers. Private schools also have lower levels of multi-grade teaching (where one teacher simultaneously teaches multiple grades) than public schools (24\% vs $79 \%$ ). ${ }^{9}$ Though these private schools are low cost, they still charge fees, whereas public schools are free. Thus, students attending these private schools come from relatively more advantaged backgrounds, as measured by parental education, occupation, and assets. ${ }^{10}$

\section{Data}

\subsection{Measuring management in low and middle-income countries (LMICs): the Development WMS (D-WMS)}

The original World Management Survey (WMS) project started in 2002 and has since then collected over 30,000 data points on the quality of management practices in establishments in the manufacturing, retail, education and healthcare sectors across 39 countries. ${ }^{11}$ The

\footnotetext{
${ }^{8}$ The transparent criteria used to determine teachers priority for transfer requests include length of service (or seniority), spousal job postings (for those with spouses who are also employed by the government), and duration spent in the current post.

${ }^{9}$ All figures reported in this section are based on Tables 3, 4, and 5 of Muralidharan and Sundararaman (2015). We present a comparison of key metrics in Table A1.

${ }^{10}$ In addition to being true in our sample, this is also seen in several other studies (Tooley; 2009; Muralidharan and Kremer; 2008; Vennam et al.; 2014; Singh; 2015).

${ }^{11}$ For a review of the latest WMS public dataset, see Scur et al. (2021). For the first paper on WMS measurement in schools, see Bloom et al. (2015). More information on the WMS project can be found at
} 
methodology involves an interview lasting approximately one hour with the senior-most manager at the establishment (for schools, this is the head teacher or principal). Highly trained analysts score the manager responses on a set scale of 1 to 5 based on a common scoring rubric. A score of 1 means there are no processes at all or very little processes in place, while a score of 2 means there are some informal processes in place mainly adopted by the headteacher herself (as opposed to some formal "school policy"). A score of 3 means there is a formal process in place, though it has weaknesses such as not being followed all the time or properly. Scores of 4 and 5 indicate increasing levels of adherence and embeddedness of the practices such that they are part of the culture of the school.

The distribution of scores for schools in high income countries span almost the entire range of the WMS scores, from 1 to a little above 4. LMICs (and especially schools in LMICs) have much lower scores on average, often bunching at the minimum score of 1 . To better capture variation in this thick bottom tail, we developed and use an enhanced measure of management quality for this paper — which we refer to as the Development WMS (DWMS). ${ }^{12}$ The D-WMS adds granularity to the measurement of management practices, while maintaining comparability with the original WMS in two ways: first, it expands the number of questions in each domain by a factor of three to separately capture the existence, use, and monitoring of various management practices. Second, it expands the scoring grid to allow for half points between 1 and 5, relative to the original WMS that only allowed integer scores. Put together, it enables a six-fold increase in the granularity of measurement of management quality. We discuss each innovation below.

\subsubsection{Expansion to improve measurement of management quality}

The WMS measures 20 "topics" that each include a set of questions that help the interviewer gather the appropriate information to score based on a set rubric. For each topic, there are three broad types of questions that interviewers use: first they ask about the existence of the practice (for example, does the school even have performance indicators and which ones), then they ask about the usage of the practice (how is it implemented, how often it is used) and finally they ask about the monitoring of the practice itself (how do they keep track that it is being understood and used effectively). In the original WMS these three factors were embedded in each score, while in the D-WMS they are explicit and require separate scores. This approach reduces measurement error by providing a much tighter scoring rubric and

www.worldmanagementsurvey.org.

${ }^{12}$ This paper supersedes the note in Lemos and Scur (2016), which describes the protocols for implementation of the D-WMS but does not validate the instrument by correlating the resulting management scores with independent measures of teaching practices and school productivity (which this paper does). 
limiting the amount of judgment that interviewers need to apply in coding responses. This is especially important for LMIC settings, where high quality interviewers may not be available or affordable (the original WMS was coded by MBA students from leading universities).

The expansion enables a better understanding of management practices, and the gaps between existence and use of tools and techniques. As shown by Muralidharan and Singh (2020), public schools in India often have good policies on paper, but these are not matched by actual practice. We found evidence of similar gaps in our field pilots, and adapted the survey instrument accordingly to capture distinctions between the existence and use of various management practices. ${ }^{13}$ Using survey instruments that capture this distinction will be especially useful for research on the effectiveness of management interventions in LMICs.

\subsubsection{Expansion to capture greater variation across the scoring scale}

The scores in low and middle income income countries in the original WMS rarely go beyond 3. To capture finer variation in the lower tail, our expanded survey instrument measures the level of adoption of management practices on a scale of 1 to 5 , in increments of 0.5 for each of the 20 topics. In AP public schools, the distribution of the comparable WMS peoplemanagement scores would have a mode of 1. By allowing for half scores to be awarded, we can distinguish between a school that has absolutely no practices in place (score of 1) and one that has some semblance of practices in place but that they are still rather ad-hoc (score of 1.5). We can also distinguish between schools that have an informal practice in place (score of 2) and a "good" informal practice in place that is almost like "formal school policy" (score of 2.5). We provide a more detailed example of the scoring of management practices in Appendix B.

\subsubsection{Building comparable scores}

To build the comparable scores, we average the three sub-scores for each of the 20 topics and take the average across these topics to construct scores for overall management, operations management, and people management. ${ }^{14}$ To build comparable metrics to the WMS, we recast the averages for each of the topics into the next lowest whole number. This is because

\footnotetext{
${ }^{13}$ For example, a headteacher that we visited in AP during the pilot showed us a great report card that they use to measure student achievement (Figure B1). When asked what they do with the report cards and the information, they showed us a storage spot where all the data was kept safely but unfortunately also not used or even usable. This is similar to findings reported in Muralidharan and Sundararaman (2010).

${ }^{14}$ The questions and training are identical, and the information gathered that forms the basis of the scoring is consistent with WMS tools. The main contribution of the D-WMS is to enable a systematically more granular coding of the same information.
} 
the WMS scoring guidelines are to score in a strictly increasing gradient, such that if a school does not have processes that are good enough to reach a score of 3 , then they would have to be given a 2 (regardless of how close they would be to a 3 ). In the D-WMS grid, they would be awarded a 2.5. This means that it is simple to take each half point score and round down to the nearest integer and mimic the original WMS scoring methodology. For the cross-country comparisons in Figures 1 and A1 only, we use the WMS-comparable score and normalize relative to the full global dataset. For the rest of the analysis in this paper, we use the D-WMS scores and normalize relative to only the AP sample (since those comparisons are within the state).

Consistent with the broader literature based on WMS surveys, we present and analyze both the overall management score, and also the component scores on operations and people management. The operations-management score is based on the first 14 questions on the D-WMS, and the people-management score is based on the last 6 questions (see Tables B1 and B2 in Appendix B for the full list of 20 questions). Throughout this paper, we use the term "people management" to refer to the score obtained on the D-WMS survey (consistent with the use of the term in the WMS literature), and the term "personnel management" to refer to broader personnel related actions taken by school leaders.

Figure 2 shows the difference between the D-WMS scores and the WMS-comparable versions of the scores. The D-WMS distribution captures a mechanical shift to the right relative to the WMS equivalent (due to the rounding down of scores under the WMS rubric). However, the D-WMS also captures meaningful new variation between scores of 1 and 2, and 2 and 3 that change the shape of the distributions. This is seen most clearly in the distribution of people-management scores distribution in the public sector, where under WMS scoring guidelines, $80 \%$ of schools would have the lowest score of 1 . In contrast, the D-WMS provides much more granular information with only $6 \%$ of schools having a score of exactly $1 .{ }^{15}$

We collected D-WMS data for a random sample of schools in the APSC project sample from January to May 2013 through face-to-face interviews with school headteachers. Each interview lasted approximately 1.5 hours and was carried out by two enumerators a primary interviewer and secondary note-taker — who reviewed their notes immediately after the interview and scored the practices according to the scoring manual and grid. The enumerators passed a one-week intensive D-WMS training session prior to field work.

\footnotetext{
${ }^{15}$ Note that the binning in the histogram in Figure 2 makes it appear that around $20 \%$ of schools have a score of 1 under the D-WMS as well. However, this bin includes values up to 1.1 and only $6 \%$ of schools score at the actual lower bound of 1 .
} 


\subsection{School, teacher and student data: the APSC dataset}

The main school-teacher-student data from the APSC project is explained in Muralidharan and Sundararaman (2015) and spans the 4 school years of the project in AP (2008-09 to 2011-12). We use several variables to build measures from this dataset: student value added, teacher value added, an index of teacher practices, teacher wages, and a measure of teacher selection and retention.

For student value added (SVA) and teacher value added (TVA), we use a panel of subjectspecific test scores from tests administered by the APSC project team for Telugu (language) and Math, along with teacher assignments into these subjects. We estimate SVA by using the residuals of a regression of the end of year test score on the previous year's test score for each student, and estimate TVA using the Chetty et al. (2014) method. ${ }^{16}$ This method yields a TVA estimate for each teacher and year, using information from all years and subjects taught by each teacher.

We construct a teacher practices index using the set of questions in the teacher questionnaires that related to classroom practices, along with audit data from classroom observation visits. These were collected independent of the student tests and the D-WMS management survey. We aggregated the sixteen items (fourteen self-reported practices and two auditbased measures of teacher presence and likelihood of being found teaching) into a single index using the Anderson (2008) method. ${ }^{17}$ A full description of each measure of teaching practice is provided in Appendix B.4; we also present simple correlations of each teaching practice with student value added in Figure B2.

Data on teacher wages are based on self-reports by teachers for all 4 years. Data on teacher turnover and retention is from the second year only. The APSC project collected data on the full roster of teachers, that tracked which teachers had moved out and which ones had transferred in, only in the first two years of the project. For each school, we identify the highest and lowest value added teacher within the school using our measure of TVA and construct a measure of "good HR outcome" based on the transfer information between years 1 and 2. The variable takes a value of 1 when the highest value added teacher is retained in the school or transferred into the school, or the lowest value added teacher is transferred out of the school. It takes a value of zero otherwise.

The combined dataset of APSC-DWMS data includes 299 schools, 190 private and 109 public schools. Note that we only measure management quality once in each school, at

\footnotetext{
${ }^{16}$ For a summary and discussion of this method, see Appendix B.3.

${ }^{17}$ This methodology weights the impact of the included variables by the sum of their rows in the inverse variance-covariance matrix, thereby assigning greater weight to questions that carry more "new information".
} 
the end of the study period, and assign this score to the school for all years of student and teacher data. ${ }^{18}$ Our main analysis includes data for Telugu and Math tests for 15,305 students; 12,661 from private schools and 2,665 from public schools. Overall, our sample has 35,964 observations over four years in an unbalanced panel. There are a total of 1,171 teachers in our sample; 864 in private schools and 307 in public schools.

\section{Results}

\subsection{Management quality and global comparisons}

Figure 1a shows the comparable standardized scores of public school management across a set of countries surveyed using the WMS (UK, Sweden, Canada, US, Germany, Italy, Brazil and India) and the D-WMS (Mexico, Colombia, and Andhra Pradesh). The D-WMS scores were re-scaled to match the WMS scoring convention: all half points were rounded down to the next lowest whole point for each survey question (for example, all scores of 2.5 were recast to 2) and the management indices and standardization were based on these comparable scores. The scores are standardized relative to the global distribution. The high-income country mean is $0.975 \sigma$, and the score for AP public schools is $-1 \sigma$. Thus, the average public school in AP scores almost two standard deviations below the average in the high income countries in the WMS.

To place these scores in context, Figure $1 \mathrm{~b}$ plots the standardized management scores against the log of the 10-year average GDP per capita for these countries. We see that there is a robust positive correlation between countries' GDP per capita and the quality of school management. Though public school management scores in AP are substantially lower than high-income country averages, their scores are not an outlier after controlling for log per-capita income.

These facts are directly relevant for understanding the variation in education system productivity across countries. There is evidence from comparable cross-country assessment data that students from richer countries perform better than those from poorer countries of the same age (OECD; 2019). Further, there is also evidence that the labor-market returns to each year of schooling is higher for students educated in richer countries (Schoellman; 2011). However, there is very little evidence on the drivers for this fact or their relative importance.

\footnotetext{
${ }^{18}$ Thus, our analysis treats management as a "fixed characteristic" of the school throughout the study period and does not aim to study inter-temporal variation in management quality within schools. Prior research suggests that management practices are slow-moving and difficult to change even with interventions, so this is a reasonable assumption in this context (e.g., Gibbons and Henderson; 2012).
} 
One likely explanation is that higher-income countries' education systems have more inputs per student (including having more educated parents). However, it is also possible that there is variation in the productivity of these inputs across countries. As such, to the extent that the quality of school management is correlated with the productivity of school systems (as we show below), Figure 1b suggests that poorer management quality may be an important contributor to the lower productivity of education systems in lower-income countries.

The discussion above is analogous to the "growth accounting" literature that has aimed to decompose variation in cross-country GDP per capita into variation in inputs (land, labor, and capital — both physical and human) and variation in total factor productivity (TFP) (Caselli; 2005). Given the growing interest in understanding the comparative productivity of education systems across countries (Pritchett; 2015; Singh; 2019), and investments in comparable data on learning outcomes across countries (Filmer et al.; 2020), it may be useful to conduct a similar accounting exercise to explain variation in the effectiveness of education systems. Since management quality is likely to be an important component of TFP, the D-WMS can be a useful measurement tool for such an exercise. This would be analogous to the approach taken by Bloom et al. (2016) for manufacturing.

Turning from cross-country comparisons to AP-specific facts, Table 1 presents management scores for public and private schools for each of the 20 management practices in the survey. It also presents scores on operations and people management, and the 10-90 percentile range of scores. Figure $3 \mathrm{a}$ shows the distribution of the AP D-WMS management scores for public and private schools.

The average public school has a D-WMS management score of 1.81 while a school at the 90th percentile has a score of 2.05, both suggesting weak management practices throughout the support of the distribution. Private schools, in contrast, are significantly better managed, scoring 0.34 points higher, or $1.36 \sigma$ greater than the public-school mean. Figure 1b provides another way to benchmark this difference and shows that the quality of management in private schools in AP is comparable to that in public schools in middle-income countries like Brazil, Colombia, and Mexico which have $\sim 4$ times greater GDP per capita than India.

This difference is especially pronounced in the area of people management. Figure $3 \mathrm{~b}$ shows the distributions of operations and people management scores for each type of school. The mean difference in the operations-management index across public and private schools is 0.12 points, which is relatively small. However, people-management scores in public schools are very low — with a mean of 1.26 , and a standard deviation of 0.18 . Private schools score 0.87 points higher in people management, which is nearly $4.8 \sigma$ higher (relative to the 
distribution of people-management scores in public schools). ${ }^{19}$

The public school distribution of people management in AP is also informative because we observe a distribution of scores despite official policies being identical across public schools. The D-WMS score, however, captures variation not just in official policies but also de facto variation in practices that may be in place at the school. For example, there may be institutional constraints to hiring and firing teachers, but they do not prevent headteachers from identifying effective and ineffective performers, and taking informal followup actions at their own level without relying on official processes or directives to do so.

\subsection{Correlates of school management practices}

Having documented the variation in management practices across schools, we now examine the correlates of this variation. Table 2 presents the coefficients of binary regressions between student, teacher and school characteristics and school management scores. Each cell reports coefficients from a single regression. Table A2 presents the multiple regression analogue.

In public schools, management quality is significantly correlated with parental socioeconomic status - positively with parental education, and negatively with the fraction of parents who are manual laborers. There is also suggestive evidence of positive correlations with teacher education and training, though these relations are not typically significant.

In private schools, management quality is strongly positively correlated with teacher education and training and also with the education level of the headteacher. It is negatively correlated with the fraction of parents who are manual laborers and (somewhat surprisingly) positively correlated with the fraction of students who belong to historically disadvantaged scheduled castes. ${ }^{20}$ Management quality is also positively correlated with school size and with average school fees, which is not surprising.

The relationships above are correlations and purely descriptive. However, what is important for interpreting our results below is that there continues to be nearly as much variation in the residualized management scores (after controlling for all the variables in Table 2) as in the raw distributions of management scores. We plot these in Figure 4 and see that the residualized distribution (especially for people management) shifts leftward for private schools

\footnotetext{
${ }^{19}$ We replicate the two cross-country figures using the people-management score in Figure A1, and see that people management quality in AP private schools are higher than those in public schools in Brazil, Colombia, and Mexico, and comparable to those in public schools in Italy (a country that is nearly seven times richer than India on PPP adjusted GDP per capita).

${ }^{20}$ One possible explanation is that religious or missionary private schools may disproportionately locate in the most disadvantaged areas and may be better managed. We are unfortunately not able to test this directly since we do not have data on whether the school is run by a missionary organization.
} 
and rightward for public schools (reflecting the greater socioeconomic advantage of students attending private schools). But, the shape of the distribution is virtually unchanged. ${ }^{21}$

This is consistent with most of the variation we observe in management scores being driven by variation in de facto practices of individual school leaders. Indeed, the meaning of D-WMS scores below 3 (which is the range where almost all schools in our sample score) is that management practices are informal and driven by individual headteachers more than policy. Thus, the correlations presented below should not be interpreted as the causal effect of any specific management practice. Rather, the results below are best thought of as connecting the literatures on school leadership and school management by providing a systematic way of getting into the "black box" of school leadership and coding specific practices of school leaders that may be correlated with variation in their effectiveness.

\subsection{School management and teacher practices}

To explore the relationship between teacher practices and school management, we build a teacher practices index and estimate the specification:

$$
\text { TeacherPractice } \text { Pjst }=\alpha+\beta M_{s}+\delta_{1} T_{j}+\delta_{2} S_{s}+\eta_{j}+\psi_{t}+\varepsilon_{i j s t}
$$

where Teacher Practice $_{i j s t}$ is the index of sixteen teaching practices (described in Appendix B.4) for teacher $i$, teaching subject $j$, at school $s$, at time $t . M_{s}$ is the z-score of each management index, the set of controls included are those described in Table $2: T_{j}$ are the teacher and headteacher controls, $S_{s}$ are the school controls including the school averages of student characteristics in Table 2. $\eta_{j}$ and $\psi_{t}$ are subject and year fixed effects. Standard errors are clustered at the school level.

Table 3 reports the results separately for public and private schools; for overall, operations, and people-management scores; and with and without the controls listed above. We see a strong and highly significant correlation $(p<0.01)$ in all 6 columns in Panel A (with no controls). Coefficients are slightly smaller but substantively unchanged and still significant after including a full set of controls (Panel B). Thus, the quality of overall, operations, and people management are all strongly correlated with independently recorded measures of teaching practice in both public and private schools.

This result helps to validate the content of the D-WMS measurement tools as capturing

\footnotetext{
${ }^{21}$ The raw (and residualized) standard deviations of the distributions are as follows. Private schools operations management: $0.93 \sigma(0.85 \sigma)$; private schools people management: $0.55 \sigma(0.61 \sigma)$; public schools operations management: $1.02 \sigma(0.99 \sigma)$; public schools people management: $0.39 \sigma(0.53 \sigma)$.
} 
elements of management quality that are able to meaningfully predict classroom teaching practices. It is also a contribution to the management literature more broadly where it has typically not been possible to observe (and correlate) both WMS-comparable management scores and measures of employee behavior in their core tasks in the same data set.

\subsection{School management and student value added}

Next, we examine the correlations between management scores and school productivity, measured by student value added. We do so by running the following specification for public and private schools, separately:

$$
\text { ValueAdded }_{p j s t}=\alpha+\beta M_{s}+\theta_{1} X_{p}+\theta_{2} T_{j s}+\theta_{3} S_{s}+\eta_{j}+\psi_{t}+\varepsilon_{p j s t}
$$

where ValueAdded $_{p j s t}$ is the student value added for student $p$, subject $j$, at school $s$ in year $t . M_{s}$ is the z-score of each management index. We estimate Equation 2 both with and without controls. The set of controls included are those described in Table 2: $X_{p}$ are the individual student controls, $T_{j}$ are the teacher and headteacher controls, $S_{s}$ are the school controls including the school averages of student characteristics in Table 2. $\eta_{j}$ and $\psi_{t}$ are subject and year fixed effects. Standard errors are clustered at the school level.

We also estimate the relationship between management quality and student value addition using a lagged test-score specification, where the outcome variable is test scores $\left(T S_{p j s t}\right)$ in year $t$ and we include lagged test scores on the right-hand side $\left(T S_{p j s, t-1}\right)$. We estimate:

$$
T S_{p j s t}=\alpha+\beta M_{s}+\theta_{0} T S_{p j s, t-1}+\theta_{1} X_{p}+\theta_{2} T_{j s}+\theta_{3} S_{s}+\eta_{j}+\psi_{t}+\varepsilon_{p j s t}
$$

Table 4 presents these results without controls (Panel A) and with the full set of controls (Panel B), and for public schools (columns 1-4) and private schools (columns 5-8). Table A4 presents the results from the lagged test-score specification. Since the results are very similar across both approaches, we present those from Equation 2 in the main tables, and Equation 3 in the Appendix. ${ }^{22}$

Starting with public schools, we see a strong and significant correlation $(p<0.01)$ between all management practices (overall, operations, and people) and student value-added (SVA). However, variation in people management seems to matter much more (around 3 times more) for explaining variation in school effectiveness. We see this both by comparing columns 3 and

\footnotetext{
${ }^{22}$ We do not include a control for a student's voucher-winning status in Equation 3 to keep the set of controls consistent across public and private schools. Results are unchanged if we include this control.
} 
2 , and in column 4 when we include both component scores as regressors. The results are practically unchanged when we include a full set of controls (Panel B): both magnitudes and significance of coefficients are very similar across Panels A and B. Results from the lagged test-score specification are also very similar (Table A4).

While these results are based on correlations, they provide strong suggestive evidence that better management practices - especially personnel management practices — are likely to matter for school productivity. The value-added specification mitigates several omitted variable concerns, and the robustness to inclusion of a wide variety of controls provides additional reassurance on this front. Further, since official policies are identical across all public schools, the variation in management practices reflect de facto practices that are implemented at the school level. Thus, the appropriate way to interpret our results is not as the causal impact of specific practices, but as getting into the "black box" of variation in school leaders' effectiveness by codifying their practices and identifying common patterns in the practices of effective school leaders. In particular, school leaders who implement better personnel management practices appear to be able to deliver greater value addition.

Turning to private schools (Table 4: columns 5-8), we see that the correlations are smaller and not significant between SVA and either overall or operations management scores. Peoplemanagement scores are significantly correlated with SVA even in private schools (in both columns 7 and 8), but the magnitude is much smaller than in the case of public schools. Results are very similar both without and with controls, and in the lagged test-score specification (Table A4).

These results provide consistent evidence that the quality of personnel management seems to matter for productivity both across public and private schools. However, one reason that the variation in personnel management quality may matter more in explaining variation in public school productivity is that the average level of personnel management is higher in private schools to begin with. Thus, given the very low base levels of personnel management in public schools, the marginal returns to even modest improvements may be high. The same reasoning may explain why overall and operations management scores are significantly correlated with SVA in public schools but not in private schools.

Next, we examine the extent to which variation in student value added across public and private schools is correlated with management quality. We do so by pooling the student data from public and private schools and estimating the following equation:

$$
\text { ValueAdded }_{p j s t}=\alpha+\beta M_{s}+\lambda_{1} P R I_{s}+\lambda_{2} S C O_{p}+\theta_{1} X_{p}+\theta_{2} T_{j s}+\theta_{3} S_{s}+\eta_{j}+\psi_{t}+\varepsilon_{p j s t}
$$


where ValueAdded Vjst $_{\text {is }}$ the student value added for student $p$, subject $j$, at school $s$ in year $t . M_{s}$ is the z-score of each management index. $P R I_{s}$ is a private school indicator, and $S C O_{s}$ is an indicator for whether a student was a scholarship recipient in the Muralidharan and Sundararaman (2015) AP School Choice Experiment. The set of controls included are those described in Table 2: $X_{p}$ are the student controls, $T_{j}$ are the teacher and headteacher controls, $S_{s}$ are the school controls including the school averages of student characteristics. $\eta_{j}$ and $\psi_{t}$ are subject and year fixed effects. Standard errors are clustered at the school level. We also estimate these relationships using the lagged test-score specification below:

$$
T S_{p j s t}=\alpha+\beta M_{s}+\lambda_{0} T S_{p j s, t-1}+\lambda_{1} P R I_{s}+\lambda_{2} S C O_{p}+\theta_{1} X_{p}+\theta_{2} T_{j s}+\theta_{3} S_{s}+\eta_{j}+\psi_{t}+\varepsilon_{p j s t}
$$

Results from Equation 4 are reported in Table 5. Without any controls (Panel A), we see that the average private school appears to have an annual value added of $0.35 \sigma$ higher (column 1). This is not a causal estimate. Our goal is simply to provide an accounting decomposition of the extent to which this private school "premium" can be accounted for by stronger management practices. ${ }^{23}$ We see that including overall or operations management scores reduce the private school premium slightly but do not meaningfully change the results (columns 2-3). However, including a control for people-management scores sharply reduces the private school premium and renders it insignificant (columns 4-5).

Patterns of results are similar with controls (Panel B). The private school premium is larger with controls, likely reflecting the lower average teacher education, experience, and training in the private schools (Table A1). Thus, the pure private school productivity premium may be even larger after accounting for their lower input quality. As in Panel A, including people-management scores significantly reduces the estimated private school premium: the magnitude falls by more than half (columns 4-5). Taken together, the significantly greater quality of personnel management appears to be a key driver of the private school premium in this setting. We see the same results from estimating the lagged test-score specification in Equation 5 (Table A5).

\footnotetext{
${ }^{23}$ The significant negative coefficient on the "scholarship" variable suggests that the average voucherwinning student in the APSC study did not benefit from this private school "premium", which is consistent with the experimental evaluation of the voucher program that found modest to no test-score gains from winning a voucher to attend a private school (Muralidharan and Sundararaman; 2015). Readers are referred to that paper for a discussion of potential reasons for this result.
} 


\subsection{Personnel management across public and private schools}

We now examine a direct measure of effective personnel management in schools - which is the extent to which teachers are rewarded for being more productive, measured by their value added. We examine this question on both the intensive margin of wages, and the extensive margin of hiring and retention. We study the relationship between teacher pay and productivity using the following specification:

$$
\text { LnWages }_{j s}=\alpha+\beta_{1} M_{s}+\beta_{2} P R I_{s}+\beta_{3} T V A_{j s}+\beta_{4} P R I_{s} \times T V A_{j s}+\theta_{1} T_{j s}+\theta_{2} S_{s}+\varepsilon_{j s}
$$

where LnWages $_{i s}$ is the average log of wages of teacher $j$ in school $s$ over all years the teacher taught at each school. $P R I_{s}$ is an indicator for private school. $T V A_{i s}$ is the teacher value added measure (estimated as in Chetty et al. (2014)), averaged across the years the teacher taught at the school. The TVA measure is normalized to have a mean of zero and standard deviation of $1 . T_{j}$ are the teacher and headteacher controls, $S_{s}$ are the school controls including the school averages of student characteristics from Table 2. Standard errors are clustered at the school level.

Results are presented in Table 6. Panel A reports the raw correlations without controls, and Panel B includes all controls listed above. Columns (1) to (3) include only public school teachers and Columns (4) to (6) include only private school teachers. Column (7) includes the full sample of teachers across public and private schools.

We find no correlation between pay and productivity in public schools, with or without controls, reflecting a rigid compensation schedule that is mainly based on qualifications and seniority. ${ }^{24}$ If anything, pay and productivity appear (insignificantly) negatively correlated in public schools. This is consistent with other studies finding evidence of lower effort among older and more senior teachers (who are paid more). ${ }^{25}$ Unsurprisingly, there is also no correlation between management quality and teacher pay in the public sector given that headteachers have no authority over teacher pay.

In contrast, teacher pay in private schools is strongly positively correlated with TVA. Without any controls, a teacher who is able to improve average student test scores by one additional standard deviation earns about $42 \%$ higher wages (Panel A, Column 4)). This relationship is positive and significant even after including all controls listed in Table 2, and

\footnotetext{
${ }^{24}$ This is also consistent with evidence from the health sector where Das et al. (2016) show that there is no correlation between doctor pay and quality of care provided in public clinics in India.

${ }^{25}$ For instance, Kremer et al. (2005) find that older and more senior teachers in public schools in India are significantly more likely to be absent, and are also likely to be paid more.
} 
we estimate that such a teacher earns about $26 \%$ higher wages (Panel B, Column 4)). This wage premium is seen even after controlling for observable characteristics such as education, experience, and training suggesting that private school managers are able to identify and reward effective teachers. Doing so is a core feature of effective personnel management and we see that the superior people-management scores in private schools are reflected in this independent metric.

Turning to management scores, we see that teachers in better managed schools are paid a wage premium (Panel A, Columns 5 and 6) over and above getting paid more for being more effective. This may reflect selection: management quality is positively correlated with school size and school fees (Table 2) which may directly affect teacher wages. ${ }^{26}$ Indeed, we see that this correlation is not significant in Panel B after including the full set of controls in Table 2 while the relationship between teacher pay and productivity continues to be so.

Combining the data across public and private schools, we see that the levels of teacher salaries are much lower in private schools, but more effective teachers are paid more in private schools (Column 7). ${ }^{27}$ Our results are similar to and consistent with those found in Pakistan by Bau and Das (2020). They also find no significant relationship between teacher wages and TVA in the public sector, but find a significant positive correlation in the private sector.

Turning to the extensive margin, we estimate:

$$
\text { HRoutcome }_{i s}=\alpha+\beta_{1} M_{s}+\beta_{2} P R I_{s}+\zeta S_{s}+\varepsilon_{i s}
$$

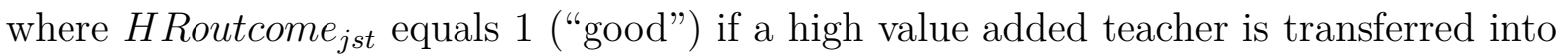
or retained in the school, or if a low value added teacher is transferred out. It takes a value of 0 otherwise. $M_{s}$ is the management index of interest (operations or people), and $P R I$ is a private school indicator. $S_{s}$ are the school controls including the school averages of student characteristics from Table 2. Standard errors are clustered at the district level.

Table 7 reports the results. We see that private schools on average are less likely to have a good HR outcome on the extensive margin (Column 1). This reflects the fact that they have much higher rates of teacher turnover, and so they are more likely to lose high-performing teachers. However, we see that better managed private schools are significantly more likely to have a positive HR outcome, again consistent with patterns found in manufacturing firms from Bender et al. (2018) and Cornwell et al. (2021). When we include the full set

\footnotetext{
${ }^{26} \mathrm{~A}$ channel of selection is consistent with results in Bender et al. (2018) and Cornwell et al. (2021), who find that better managed firms are more likely to hire and retain more effective workers and managers.

${ }^{27}$ The F-test on the sum of the TVA and Private $\mathrm{x}$ TVA coefficients yields a p-value of 0.0002 for the specification in Panel A and 0.0076 for the specification in Panel B, lending further support to this point.
} 
of controls, only the people-management score is significant, consistent with the outcome variable being more relevant to personnel management. There is no meaningful correlation between management quality and teacher selection or retention in public schools.

Note that detailed teacher roster data (including on transfers and new entrants) was collected only in the first 2 years of the APSC project and so our HR outcomes are defined using only the second-year teacher roster. This limits the sample size and the results above should therefore be treated only as suggestive. We present them for completeness since we are not aware of any prior evidence on this question. Testing for this result in larger samples and over longer time periods is an important area for future research.

\section{Discussion and Conclusion}

There is a growing recognition that the quality of management practices may be an important determinant of productivity differences across firms and countries (Syverson; 2011; Bloom et al.; 2014, 2016; Scur et al.; 2021). In this paper, we measure management quality of public and private schools in a low-capacity setting; plot these against global benchmarks (with and without income adjustments); study the correlations between management quality and both teacher practices and school productivity; and examine correlations between teacher pay and productivity across public and private schools. We do so by developing and deploying a new measurement tool (the D-WMS) that permits both greater granularity of measurement of management practices in low capacity settings and comparability with the widely used WMS surveys; and by combining this D-WMS data with panel data on student test scores across public and private schools and a rich dataset of school and teacher characteristics.

Our results strongly suggest that management quality - and especially the quality of personnel management - is likely to be an important component of school productivity. Better managed schools also have better teaching practices, and add more value to student learning. Extrapolating from this micro-evidence using school-level variation, the plots of management scores across countries suggest that cross-country differences in school management quality may play a role in explaining the documented differences in school productivity across countries (Schoellman; 2011; Singh; 2019).

More generally, our results contribute to a better understanding of public sector personnel economics and to the comparative study of management and productivity across the public and private sectors. In particular, our data highlight that the quality of personnel management in the public sector is especially poor and we directly show the lack of correla- 
tion between pay and productivity for public sector workers. ${ }^{28}$ In contrast, private schools have much higher personnel management scores and pay more effective teachers more (even after controlling for several observable characteristics). Our results suggest that even modest improvements in public school management practices at the level of school leaders may be highly effective at improving teacher effort and effectiveness.

Consistent with this view, there is considerable interest among donors, policy makers, and private organizations (both for and non profit) in designing and implementing programs to improve school management in LMICs. The belief that such interventions can be effective is also supported by evidence of success in the US (Fryer; 2014, 2017).

At the same time, recent evidence suggests that improving management quality in public schools at scale in LMICs is not easy. For instance, a large-scale randomized evaluation of a flagship school quality improvement program in India found that it had no impact on either teaching practices or learning outcomes, despite the program design reflecting several global "best practices" (Muralidharan and Singh; 2020). Thus, much more research is needed to learn about effective and cost-effective ways of improving school management at scale. The D-WMS measurement tools developed for this paper can be a useful complement to such efforts by enabling researchers to use a common and comparable scale across studies to (a) measure baseline levels of management, (b) measure improvements in management practice from various interventions, and (c) to experimentally study the relationship between changes in school management practices and changes in teaching practices and student outcomes. ${ }^{29}$

\footnotetext{
${ }^{28}$ These findings are consistent with a growing body of experimental evidence from developing countries that find that the default patterns of common across-the-board pay increases in public schools may not be effective (de Ree et al.; 2017), and that even modest amounts of performance-linked pay in public schools can be highly effective (Leaver et al.; 2021; Muralidharan and Sundararaman; 2011).

${ }^{29}$ In their evaluation of an ambitious school management reform in India, Muralidharan and Singh (2020) find that the program led to changes on paper but not in practice. Thus, the additional granularity of the D-WMS - that distinguishes between the existence, use, and monitoring/follow-up of various management practices - may be especially relevant for studying future school management interventions in LMICs.
} 


\section{References}

Anderson, M. L. (2008). Multiple inference and gender differences in the effects of early intervention: A reevaluation of the abecedarian, perry preschool, and early training projects, Journal of the American Statistical Association 103(484): 1481-1495.

Andrabi, T., Das, J. and Khwaja, A. I. (2008). A dime a day: The possibilities and limits of private schooling in pakistan, Comparative Education Review 52(3): 329-355.

Bau, N. and Das, J. (2020). Teacher value added in a low-income country, American Economic Journal: Economic Policy 12(1): 62-96.

Bender, S., Bloom, N., Card, D., Van Reenen, J. and Wolter, S. (2018). Management practices, workforce selection, and productivity, Journal of Labor Economics 36(S1): S371S409.

Béteille, T. (2009). Absenteeism, transfers and patronage: The political economy of teacher labor markets in India, PhD thesis.

Bloom, N., Lemos, R., Sadun, R., Scur, D. and Van Reenen, J. (2014). The new empirical economics of management, Journal of the European Economics Association 12(4): 835876.

Bloom, N., Lemos, R., Sadun, R. and Van Reenen, J. (2015). Does management matter in schools?, The Economic Journal 125: 647-674.

Bloom, N., Sadun, R. and Van Reenen, J. (2016). Management as a technology?, Working Paper 22327, National Bureau of Economic Research.

Bloom, N. and Van Reenen, J. (2007). Measuring and explaining management practices across firms and countries, Quarterly Journal of Economics 123(4): 1351-1408.

Caselli, F. (2005). Accounting for Cross-Country Income Differences, in P. Aghion and S. Durlauf (eds), Handbook of Economic Growth, Vol. 1 of Handbook of Economic Growth, Elsevier, chapter 9, pp. 679-741.

Chetty, R., Friedman, J. and Rockoff, J. (2014). Measuring the impact of teachers I: evaluating bias in teacher value-added estimates, American Economic Review 104(9): 2593-2632.

Coelli, M. and Green, D. (2012). Leadership effects: School principals and student outcomes, Economics of Education Review 31(1): 92 - 109. 
Cornwell, C., Schmutte, I. and Scur, D. (2021). Building a productive workforce: the role of structured management practices, Management Science forthcoming.

CSF (2020). State of the sector report: Private schools in india, Technical report, Central Square Foundation.

Das, J., Holla, A., Mohpal, A. and Muralidharan, K. (2016). Quality and accountability in health care delivery: Audit-study evidence from primary care in india, American Economic Review 106(12): 3765-99.

de Ree, J., Muralidharan, K., Pradhan, M. and Rogers, H. (2017). Double for Nothing? Experimental Evidence on an Unconditional Teacher Salary Increase in Indonesia, The Quarterly Journal of Economics 133(2): 993-1039.

Duflo, E., Hanna, R. and Ryan, S. P. (2012). Incentives work: Getting teachers to come to school, American Economic Review 102(4): 1241-78.

URL: https://www.aeaweb.org/articles?id=10.125\%/aer.102.4.1241

Filmer, D., Rogers, H., Angrist, N. and Sabarwal, S. (2020). Learning-adjusted years of schooling (LAYS): Defining a new macro measure of education, Economics of Education Review 77: 101971.

Finan, F., Olken, B. A. and Pande, R. (2015). The Personnel Economics of the State, NBER Working Papers 21825, National Bureau of Economic Research.

Fryer, R. G. (2014). Injecting charter school best practices into traditional public schools: evidence from field experiments, Quarterly Journal of Economics 129(3): 1355-407.

Fryer, R. G. (2017). Management and student achievement: Evidence from a randomized field experiment, Working Paper 23437, National Bureau of Economic Research.

Gibbons, R. and Henderson, R. (2012). Relational contracts and organizational capabilities, Organization Science 23(5): 1350-1364.

Glewwe, P. and Muralidharan, K. (2016). Chapter 10 - improving education outcomes in developing countries: Evidence, knowledge gaps, and policy implications, Vol. 5 of Handbook of the Economics of Education, Elsevier, pp. 653 - 743.

Gordon, R., Kane, T. and Staiger, D. (2006). Identifying effective teachers using performance on the job, The Hamilton Project White Paper 2006-1, Brookings Institution. 
Guarino, C., Reckase, M. D. and Wooldridge, J. M. (2014). Can value-added measures of teacher performance be trusted?, Education Finance and Policy .

Kane, T. and Staiger, D. (2008). Estimating teacher impacts on student achievement: An experimental evaluation, Working Paper series 1460\%, National Bureau of Economic Research.

Kane, T., Staiger, D. and Bacher-Hicks, A. (2014). Validating teacher effect estimates using changes in teacher assignments in los angeles, NBER Working Paper series 2065\%, National Bureau of Economic Research.

Kremer, M., Chaudhury, N., Hammer, J., Muralidharan, K. and Rogers, H. (2005). Teacher absence in india: A snapshot, Journal of the European Economic Association 3(2-3): 65867.

Lavy, V. and Boiko, A. (2017). Management quality in public education: Superintendent value-added, student outcomes and mechanisms, NBER Working Papers 24028, National Bureau of Economic Research.

Lazear, E. (1995). Personnel Economics, Vol. 1, 1 edn, The MIT Press.

Leaver, C., Ozier, O., Serneels, P. and Zeitlin, A. (2021). Recruitment, effort, and retention effects of performance contracts for civil servants: Experimental evidence from rwandan primary schools, American Economic Review forthcoming.

Lemos, R. and Scur, D. (2016). Developing management: An expanded evaluation tool for developing countries, Technical Report 00\%, RISE Working Paper Series.

Munoz, P. and Prem, M. (2020). Managers' Productivity and Labor Market: Evidence from School Principals, Working papers 40, Red Investigadores de Economia.

Muralidharan, K. and Kremer, M. (2008). School Choice International, MIT Press, Cambridge, MA, chapter title: Public and private schools in rural india.

Muralidharan, K. and Singh, A. (2020). Improving Public Sector Management at Scale? Experimental Evidence on School Governance India, NBER Working Papers 28129, National Bureau of Economic Research, Inc.

Muralidharan, K. and Sundararaman, V. (2010). The impact of diagnostic feedback to teachers on student learning: experimental evidence from India, The Economic Journal 120(546): F187-F203. 
Muralidharan, K. and Sundararaman, V. (2011). Teacher performance pay: Experimental evidence from India, Journal of Political Economy 119(1): 39-77.

Muralidharan, K. and Sundararaman, V. (2015). The aggregate effects of school choice: evidence from a two-stage experiment in India, The Quarterly Journal of Economics 130(3): 1011-1066.

OECD (2019). PISA 2018 Results (Volume I).

URL: https://www.oecd-ilibrary.org/content/publication/5f0\%c754-en

Pritchett, L. (2015). Creating education systems coherent for learning outcomes, Working Paper Series 15/005, Research on Improving Systems of Education.

Rainey, H. G. and Chun, Y. H. (2007). Public and private management compared, in E. Ferlie, L. E. L. Jr. and C. Pollitt (eds), The Oxford Handbook of Public Management, The Oxford Handbook of Public Management, Oxford University Press.

Ramachandran, V., Beteille, T., Linden, T., Dey, S., Goyal, S. and Chatterjee, P. G. (2016). Teachers in the indian education system: How we manage the teacher work force in india, NUEPA Research Reports Publications Series NRRPS/001/2016, National University ofEducational Planning and Administration.

Rockoff, J. (2004). The impact of individual teachers on student achievement: Evidence from panel data, American Economic Review: Papers and Proceedings 94: 247-252.

Romero, M., Sandefur, J. and Sandholtz, W. A. (2020). Outsourcing education: Experimental evidence from liberia, American Economic Review 110(2): 364-400.

Schoellman, T. (2011). Education Quality and Development Accounting, The Review of Economic Studies 79(1): 388-417.

Scur, D., Sadun, R., Van Reenen, J., Lemos, R. and Bloom, N. (2021). The World Management Survey at 18: lessons and the way forward, Oxford Review of Economic Policy 37(2): 231-258.

Singh, A. (2015). Private school effects in urban and rural india: Panel estimates at primary and secondary school ages, Journal of Development Economics 113: 16-32.

Singh, A. (2019). Learning More with Every Year: School Year Productivity and International Learning Divergence, Journal of the European Economic Association 18(4): 17701813. 
Syverson, C. (2011). What determines productivity?, Journal of Economic Literature 49(2): 326-365.

Tooley, J. (2009). The Beautiful Tree: A Personal Journey into How the World's Poorest People are Educating Themselves, Penguin, New Delhi.

Vennam, U., Komanduri, A. and Duggani, U. (2014). Changing schools in andhra pradesh, Working Paper 131, Young Lives.

Walsh, E. and Dotter, D. (2020). The impact on student achievement of replacing principals in district of columbia public schools, Education Finance and Policy 15(3): 518-542.

Woldehanna, T., Galab, S., Sanchez, A., Penny, M., Duc, L. T. and Boyden, J. (2018). Young lives: an international study of childhood poverty.

World Bank (2018). World Development Report 2018: Learning to realize education's promise, The World Bank, Washington DC. 
Figure 1: Global benchmarks

(a) Rank of comparable management z-scores

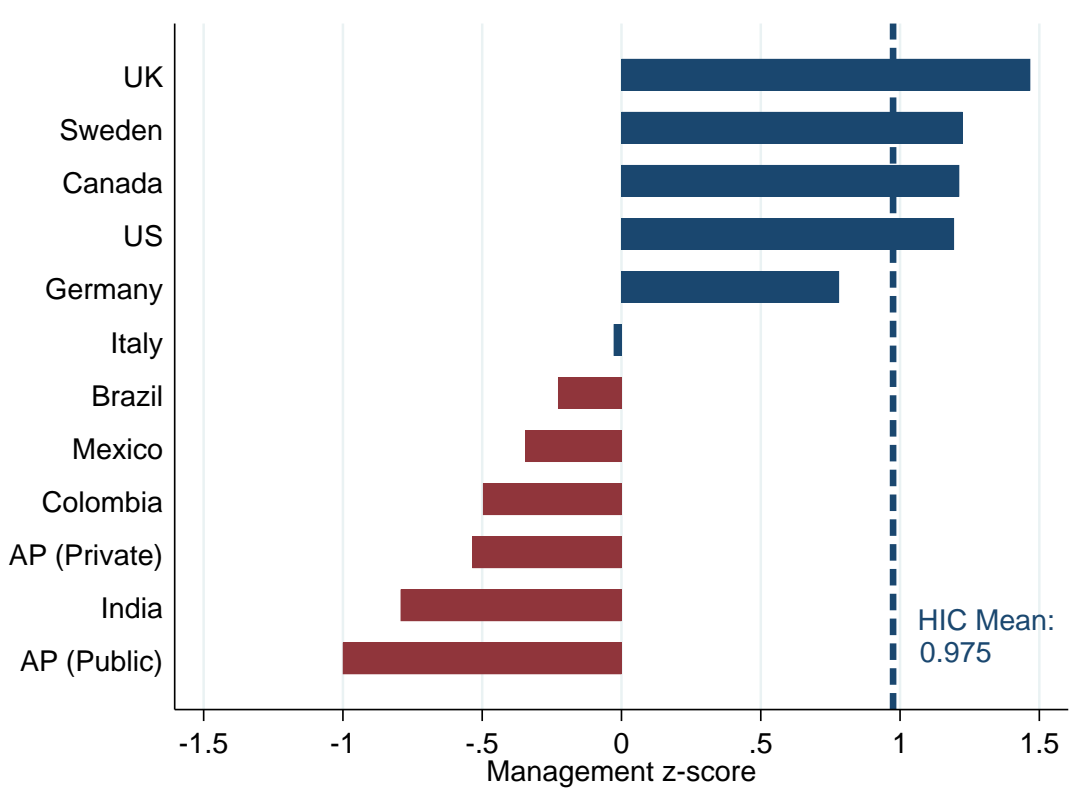

(b) Comparable management z-scores and GDP per capita

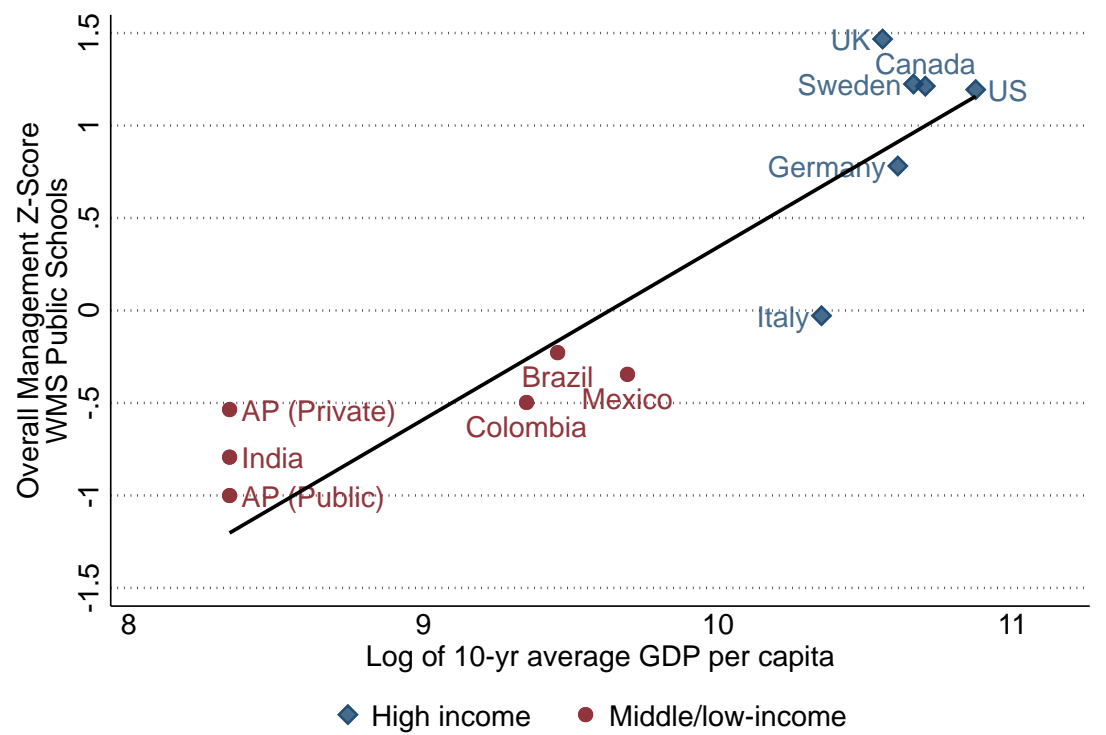

Note: This figure includes only public secondary schools from the WMS dataset (UK, Canada, Sweden, US, Germany, Italy, Brazil and India) and public primary schools from the Development WMS dataset (Andhra Pradesh, Mexico and Colombia). The Development WMS scores were re-scaled to match the WMS scoring convention: all half points were downgraded to the next lowest whole point for each survey question (for example, all scores of 2.5 were re-cast to 2 ) before indices were built. Country averages for WMS countries were estimated using sampling weights (see Appendix B for details on the weights construction). For this figure, management scores are normalized relative to the cross-country sample. Number of WMS observations are as follows: Brazil $=373$, Canada $=113$, Colombia $=447$, Great Britain $=78$, Germany $=91$, India $=130$, Italy $=222$, Mexico $=178$, Sweden $=85$, United States $=$ 193. The 10-year average GDP per capita comes from the IMF world tables, and include 2008-2018. We used India's GDP as a stand-in for Andhra Prade@6"s GPD in Panel (b). AP private school "raw" overall management score means are: DWMS $=2.15 ; \mathrm{WMS}=1.74$. AP public school "raw" overall management score means are: DWMS $=1.81 ; \mathrm{WMS}=1.48$. 
Figure 2: Distributions of the DWMS and the re-cast WMS scores in Andhra Pradesh
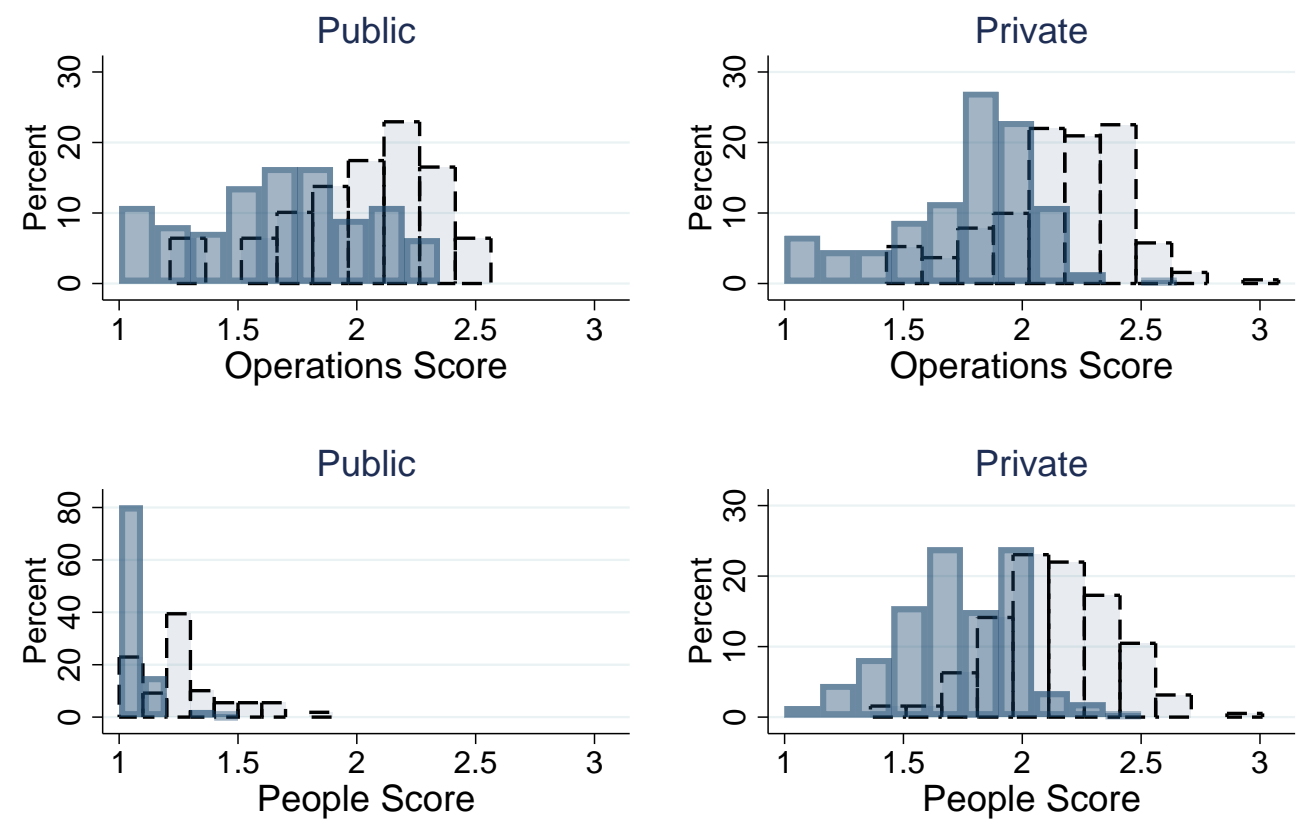

$\square$ DWMS score

WMS score

Note: This figure shows the distribution of operations and people management scores for public and private schools in our AP sample. The dashed line bars correspond to the Development WMS indices, which allows for the awarding of half scores for each measured topic. The blue solid bars correspond to the re-cast scores for each topic in the "original WMS" convention, where half scores are not allowed and thus half scores were downgraded to the next lowest integer. For example, scores of 2.5 were replaced with 2. See the Data sections and Data Appendix for more details. 
Figure 3: Distribution of management scores in Andhra Pradesh

(a) Overall management scores

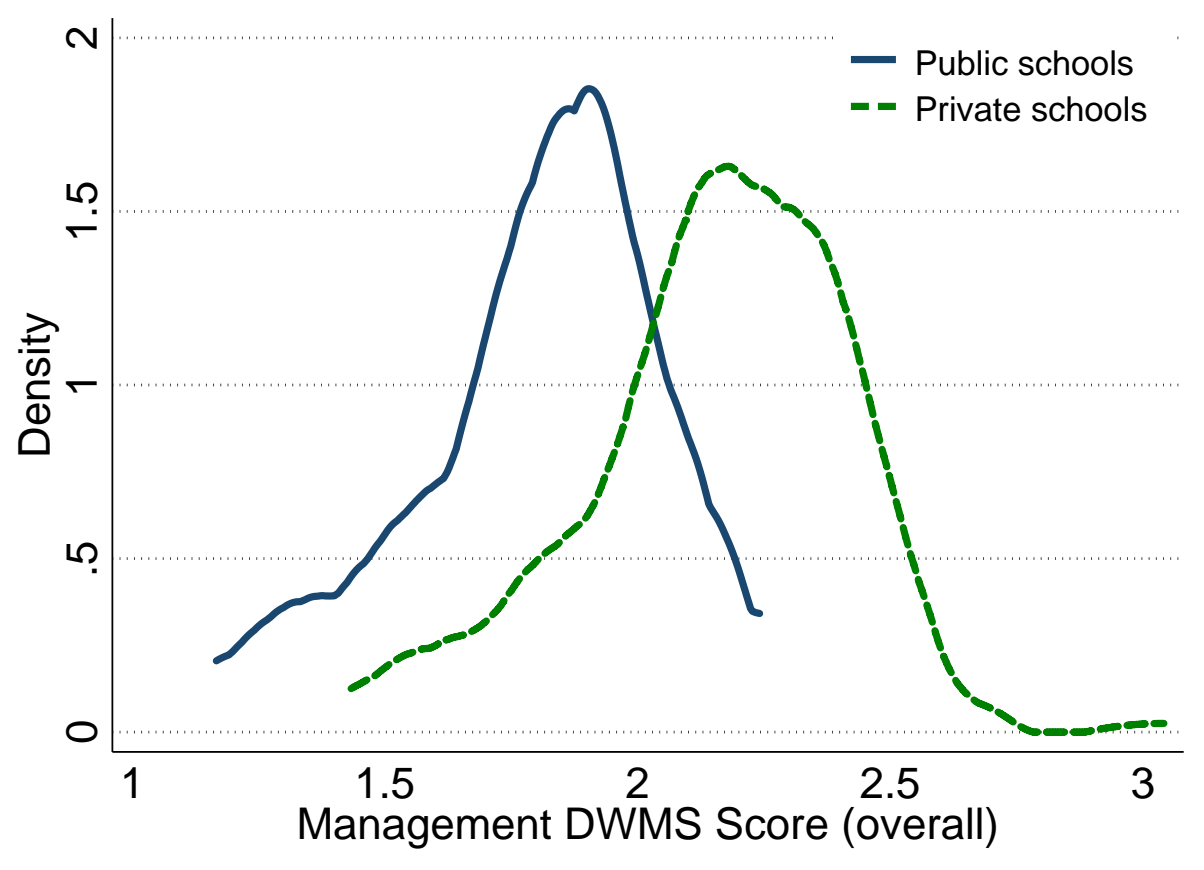

(b) People and operations management

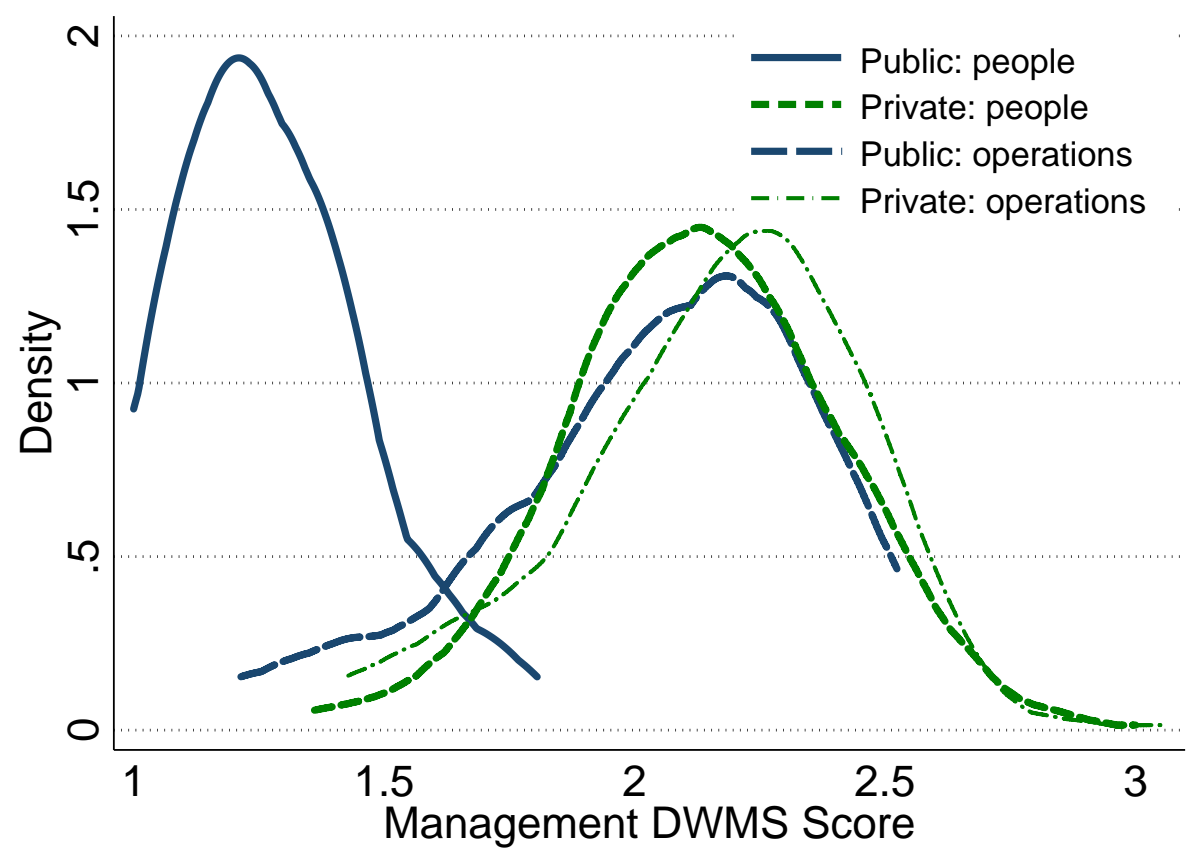

Note: This figure shows the distribution of the D-WMS overall management z-score index for public and private schools in Panel A and operations and people management z-score indices in Panel B. Standardization is relative to the full dataset, including public and private schools. Data for Andhra Pradesh (AP) is from the Development World Management Survey, with potential scores ranging from 1 to 5 in increments of 0.5. The D-WMS AP data includes 109 public schools and 190 private schools. The average D-WMS overall management score for AP private schools is $2.15(\mathrm{SD}=0.26)$. The average D-WMS overall management score for AP public schools is 1.81 ( $\mathrm{sd}=0.25)$. 
Figure 4: Distribution of management: raw vs residual

(a) Private
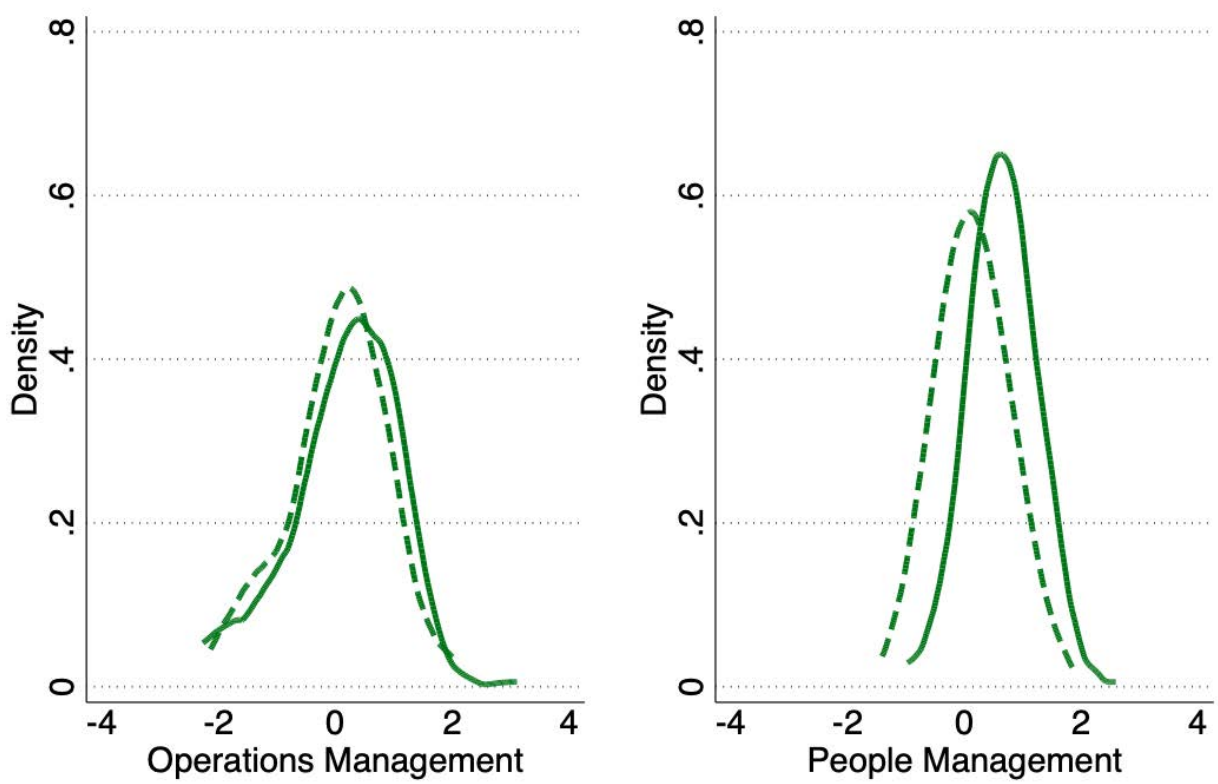

Raw score

- =- Residuals

(b) Public
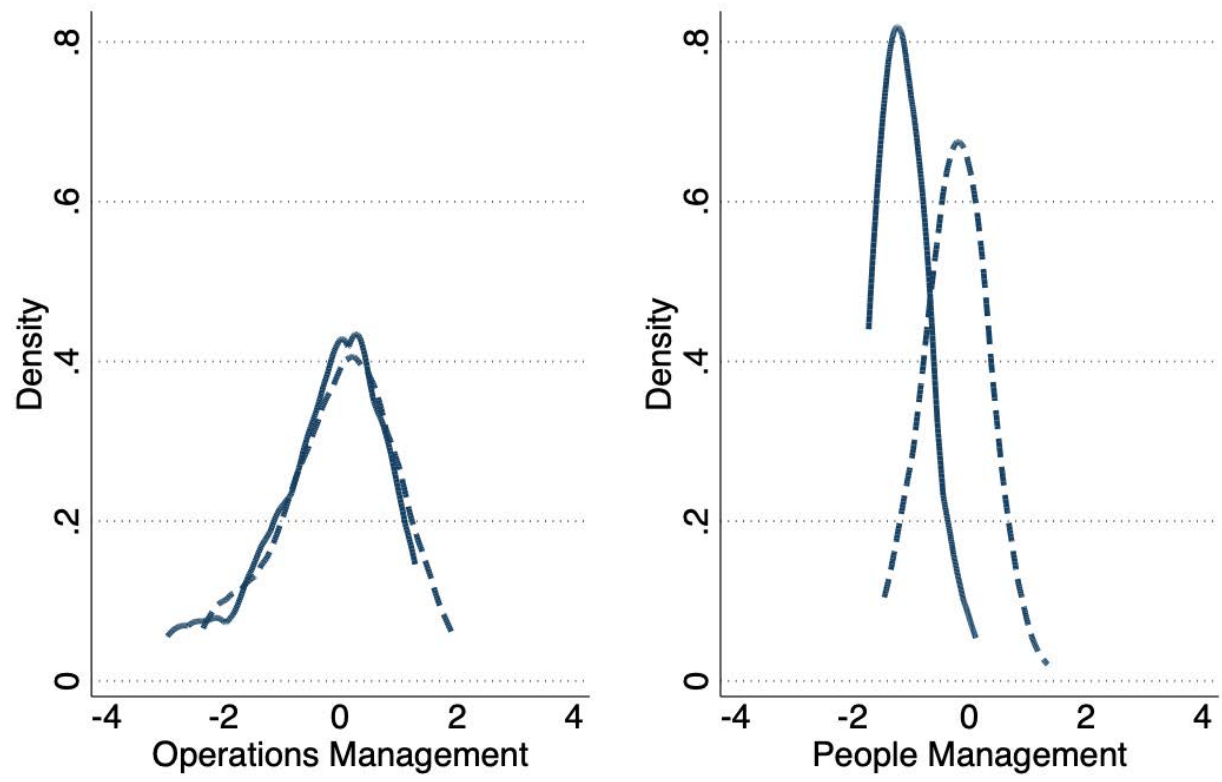

Raw score

- =- Residuals

Note: This figure plots the distribution of operations and people management D-WMS scores for private schools in Panel (a) and public schools in Panel (b). The "raw" score is the D-WMS score standardized relative to the full distribution. The residuals are from regressions of the standardized management indices on a set of student, teacher and school controls listed in Table 2. Standard deviations of each distribution are as follows. Private schools: operations raw score $\mathrm{SD}=0.93$; operations residual score $\mathrm{SD}=0.85$; people raw score $\mathrm{SD}=0.55$; people management score $\mathrm{SD}=0.61$. Public schools: operations raw score $\mathrm{SD}=1.02$; operations residual score $\mathrm{SD}=0.99$; people raw score $\mathrm{SD}=0.39$; people residual score $\mathrm{SD}=0.53$. 
Table 1: Management scores in Andhra Pradesh public and private schools

\begin{tabular}{|c|c|c|c|c|c|c|}
\hline & \multicolumn{3}{|c|}{ Public Schools } & \multicolumn{3}{|c|}{ Private Schools } \\
\hline & Mean & $\begin{array}{c}10 t h \\
\text { pct }\end{array}$ & $\begin{array}{c}90 t h \\
\text { pct }\end{array}$ & Mean & $\begin{array}{c}10 \text { th } \\
\text { pct }\end{array}$ & $\begin{array}{l}90 \text { th } \\
\text { pct }\end{array}$ \\
\hline Overall management index & 1.81 & 1.42 & 2.05 & 2.15 & 1.81 & 2.45 \\
\hline Operations average index & 2.04 & 1.58 & 2.38 & 2.16 & 1.76 & 2.46 \\
\hline Standardisation of instructional processes & 1.87 & 1.50 & 2.33 & 2.21 & 1.67 & 2.83 \\
\hline Data driven planning and student transition & 1.93 & 1.50 & 2.50 & 2.08 & 1.50 & 2.67 \\
\hline Personalization of instruction and learning & 1.98 & 1.50 & 2.50 & 2.25 & 1.67 & 2.83 \\
\hline Adopting educational best practices & 2.22 & 1.33 & 3.17 & 2.12 & 1.67 & 2.67 \\
\hline Continuous improvement & 1.89 & 1.50 & 2.33 & 2.16 & 1.83 & 2.67 \\
\hline Performance tracking & 2.24 & 1.67 & 2.67 & 2.32 & 1.83 & 2.83 \\
\hline Review of performance & 2.45 & 1.83 & 3.33 & 2.39 & 1.83 & 3.00 \\
\hline Performance dialogue & 2.23 & 1.50 & 2.67 & 2.12 & 1.67 & 2.50 \\
\hline Consequence management & 2.05 & 1.50 & 2.50 & 2.23 & 1.67 & 2.83 \\
\hline Type of targets & 1.87 & 1.17 & 2.17 & 2.04 & 1.50 & 2.50 \\
\hline Interconnection of goals & 2.11 & 1.50 & 2.50 & 2.21 & 1.50 & 2.67 \\
\hline Time horizon & 2.10 & 1.17 & 3.17 & 2.22 & 1.67 & 2.83 \\
\hline Goals are stretching & 1.90 & 1.17 & 2.33 & 1.91 & 1.50 & 2.33 \\
\hline Clarity of goals & 1.73 & 1.33 & 2.33 & 2.00 & 1.50 & 2.50 \\
\hline People average index & 1.26 & 1.03 & 1.56 & 2.13 & 1.83 & 2.47 \\
\hline Instilling a talent mindset & 1.14 & 1.00 & 1.50 & 2.48 & 2.00 & 3.00 \\
\hline Incentives and appraisals & 1.51 & 1.00 & 1.83 & 2.00 & 1.50 & 2.50 \\
\hline Making room for talent & 1.32 & 1.00 & 1.83 & 2.31 & 1.83 & 2.83 \\
\hline Developing talent & 1.41 & 1.00 & 2.00 & 2.09 & 1.50 & 2.67 \\
\hline Distinctive employee value & 1.05 & 1.00 & 1.17 & 1.96 & 1.50 & 2.33 \\
\hline Retaining talent & 1.14 & 1.00 & 1.33 & 1.97 & 1.67 & 2.33 \\
\hline Number of schools & 109 & & & 191 & & \\
\hline
\end{tabular}

Notes: The summary statistics in this table report the average and distributional statistics for the Development WMS (D-WMS) scores. The D-WMS survey instrument measures the quality of management on a scale of 1 to 5 , in increments of 0.5 for each of the 20 topics. The expanded survey instrument measures the level of adoption of management practices on a scale of 1 to 5 , in increments of 0.5 . A score of 1 means there are no processes at all or very little processes in place, while a score of 2 means there are some informal processes in place mainly adopted by the principal (as opposed to some formal "school policy"). A score of 3 means there is a formal process in place, though it has weaknesses such as not being followed all the time, or properly. A score of 4 indicate increasing levels of adherence and a score of 5 includes "grassroots" engagement with the practices such that they are part of the culture of the school. For example, in the question regarding data-driven planning and student transitions, a score of a 3 or below for this topic means performance data is not be recorded systematically with a range of tools that would allow for a more thorough understanding of a student's strengths and weaknesses. Further it is not integrated or easy to use or shared with a range of stakeholders. See Data Appendix B for a full set of questions and explanations of the survey tool. 
Table 2: Correlates of management quality: student, teacher and school characteristics

Table of coefficients: each cell is a bi-variate regression

\begin{tabular}{|c|c|c|c|c|c|c|}
\hline & \multicolumn{3}{|c|}{ Public } & \multicolumn{3}{|c|}{ Private } \\
\hline & $\begin{array}{c}(1) \\
\text { z-mgmt }\end{array}$ & $\begin{array}{c}(2) \\
\text { Z-ops }\end{array}$ & $\begin{array}{c}(3) \\
\text { z-people }\end{array}$ & $\begin{array}{c}(4) \\
\text { z-mgmt }\end{array}$ & $\begin{array}{c}(5) \\
\text { Z-ops }\end{array}$ & $\begin{array}{c}(6) \\
\text { z-people }\end{array}$ \\
\hline $\begin{array}{l}\text { Panel A: Student characteristics } \\
\text { Share female }\end{array}$ & $\begin{array}{c}0.486 \\
(0.365)\end{array}$ & $\begin{array}{c}0.577 \\
(0.455)\end{array}$ & $\begin{array}{c}0.153 \\
(0.178)\end{array}$ & $\begin{array}{l}-0.114 \\
(0.392)\end{array}$ & $\begin{array}{l}-0.105 \\
(0.421)\end{array}$ & $\begin{array}{l}-0.092 \\
(0.239)\end{array}$ \\
\hline Share scheduled caste & $\begin{array}{l}-0.145 \\
(0.225)\end{array}$ & $\begin{array}{l}-0.147 \\
(0.275)\end{array}$ & $\begin{array}{l}-0.092 \\
(0.101)\end{array}$ & $\begin{array}{c}0.726^{* *} \\
(0.299)\end{array}$ & $\begin{array}{l}0.753^{* *} \\
(0.314)\end{array}$ & $\begin{array}{c}0.434^{* *} \\
(0.205)\end{array}$ \\
\hline Share literate parents & $\begin{array}{c}0.623^{* *} \\
(0.259)\end{array}$ & $\begin{array}{c}0.699^{* *} \\
(0.317)\end{array}$ & $\begin{array}{c}0.273^{* *} \\
(0.117)\end{array}$ & $\begin{array}{c}0.124 \\
(0.278)\end{array}$ & $\begin{array}{c}0.141 \\
(0.294)\end{array}$ & $\begin{array}{c}0.050 \\
(0.172)\end{array}$ \\
\hline Share laborer parents & $\begin{array}{c}-0.565^{* *} \\
(0.219)\end{array}$ & $\begin{array}{c}-0.684^{* * *} \\
(0.255)\end{array}$ & $\begin{array}{l}-0.154 \\
(0.127)\end{array}$ & $\begin{array}{r}-0.329^{*} \\
(0.171)\end{array}$ & $\begin{array}{c}-0.387^{* *} \\
(0.184)\end{array}$ & $\begin{array}{l}-0.112 \\
(0.114)\end{array}$ \\
\hline Average household assets index & $\begin{array}{c}0.185 \\
(0.136)\end{array}$ & $\begin{array}{c}0.222 \\
(0.166)\end{array}$ & $\begin{array}{c}0.054 \\
(0.065)\end{array}$ & $\begin{array}{c}0.044 \\
(0.114)\end{array}$ & $\begin{array}{c}0.065 \\
(0.123)\end{array}$ & $\begin{array}{l}-0.009 \\
(0.073)\end{array}$ \\
\hline $\begin{array}{l}\text { Panel B: Teacher characteristics } \\
\text { Share with a degree }\end{array}$ & $\begin{array}{c}0.241 \\
(0.317)\end{array}$ & $\begin{array}{c}0.224 \\
(0.385)\end{array}$ & $\begin{array}{l}0.193^{*} \\
(0.112)\end{array}$ & $\begin{array}{c}0.656^{* * *} \\
(0.180)\end{array}$ & $\begin{array}{c}0.718^{* * *} \\
(0.195)\end{array}$ & $\begin{array}{c}0.323^{* * *} \\
(0.119)\end{array}$ \\
\hline Share with teacher training & $\begin{array}{c}0.410 \\
(0.544)\end{array}$ & $\begin{array}{c}0.449 \\
(0.669)\end{array}$ & $\begin{array}{c}0.200 \\
(0.185)\end{array}$ & $\begin{array}{l}0.453^{*} \\
(0.230)\end{array}$ & $\begin{array}{c}0.501^{* *} \\
(0.245)\end{array}$ & $\begin{array}{c}0.213 \\
(0.148)\end{array}$ \\
\hline Average teaching experience & $\begin{array}{c}0.009 \\
(0.015)\end{array}$ & $\begin{array}{c}0.017 \\
(0.018)\end{array}$ & $\begin{array}{l}-0.007 \\
(0.006)\end{array}$ & $\begin{array}{l}-0.007 \\
(0.021)\end{array}$ & $\begin{array}{l}-0.009 \\
(0.023)\end{array}$ & $\begin{array}{l}-0.001 \\
(0.013)\end{array}$ \\
\hline Average number of workdays & $\begin{array}{c}-0.008 \\
(0.008)\end{array}$ & $\begin{array}{l}-0.009 \\
(0.009)\end{array}$ & $\begin{array}{l}-0.002 \\
(0.005)\end{array}$ & $\begin{array}{c}0.000 \\
(0.006)\end{array}$ & $\begin{array}{l}-0.000 \\
(0.007)\end{array}$ & $\begin{array}{c}0.001 \\
(0.003)\end{array}$ \\
\hline Head teacher teaching experience & $\begin{array}{c}0.003 \\
(0.014)\end{array}$ & $\begin{array}{c}0.008 \\
(0.017)\end{array}$ & $\begin{array}{l}-0.007 \\
(0.005)\end{array}$ & $\begin{array}{c}0.003 \\
(0.027)\end{array}$ & $\begin{array}{c}0.001 \\
(0.028)\end{array}$ & $\begin{array}{c}0.006 \\
(0.018)\end{array}$ \\
\hline Head teacher has degree & $\begin{array}{l}-0.172 \\
(0.238)\end{array}$ & $\begin{array}{l}-0.235 \\
(0.291)\end{array}$ & $\begin{array}{c}0.004 \\
(0.102)\end{array}$ & $\begin{array}{c}0.809^{* * *} \\
(0.273)\end{array}$ & $\begin{array}{c}0.875^{* * *} \\
(0.281)\end{array}$ & $\begin{array}{c}0.414^{* *} \\
(0.188)\end{array}$ \\
\hline $\begin{array}{l}\text { Panel C: School characteristics } \\
\text { School size (\# students) }\end{array}$ & $\begin{array}{l}-0.114 \\
(0.135)\end{array}$ & $\begin{array}{l}-0.128 \\
(0.160)\end{array}$ & $\begin{array}{l}-0.050 \\
(0.065)\end{array}$ & $\begin{array}{c}0.296^{* * *} \\
(0.077)\end{array}$ & $\begin{array}{c}0.304^{* * *} \\
(0.085)\end{array}$ & $\begin{array}{c}0.184^{* * * *} \\
(0.048)\end{array}$ \\
\hline Log of total school fees & & & & $\begin{array}{c}0.186^{* *} \\
(0.073)\end{array}$ & $\begin{array}{c}0.203^{* * *} \\
(0.078)\end{array}$ & $\begin{array}{c}0.094^{* *} \\
(0.044)\end{array}$ \\
\hline Number of schools & 109 & 109 & 109 & 191 & 191 & 191 \\
\hline
\end{tabular}

Notes: Standard errors are clustered by school. z-mgmt is the ôterall standardized management score. z-ops is the standardized index of operations questions and z-people is the standardized index of people management questions. Headteacher refers to the teacher formally appointed as headteacher or the most senior teacher at the school. 
Table 3: School management practices and teacher practices

\begin{tabular}{|c|c|c|c|c|c|c|}
\hline \multirow[t]{3}{*}{ Panel A: no controls } & \multicolumn{3}{|c|}{ Public schools } & \multicolumn{3}{|c|}{ Private schools } \\
\hline & $(1)$ & $(2)$ & $(3)$ & (4) & $(5)$ & $(6)$ \\
\hline & \multicolumn{6}{|c|}{ Dependent variable: teacher practice index } \\
\hline z-management & $\begin{array}{c}0.291^{* * *} \\
(0.060)\end{array}$ & & & $\begin{array}{c}0.208^{* * *} \\
(0.051)\end{array}$ & & \\
\hline z-operations & & $\begin{array}{l}.244^{* * *} \\
(0.049)\end{array}$ & & & $\begin{array}{c}0.189^{* * *} \\
(0.046)\end{array}$ & \\
\hline z-people & & & $\begin{array}{c}0.329 * * * \\
(0.118)\end{array}$ & & & $\begin{array}{c}0.269 * * * \\
(0.085)\end{array}$ \\
\hline Observations & 740 & 740 & 740 & 1367 & 1367 & 1367 \\
\hline \# schools & 109 & 109 & 109 & 190 & 190 & 190 \\
\hline Outcome variable SD & 0.89 & 0.89 & 0.89 & 1.06 & 1.06 & 1.06 \\
\hline \multirow[t]{3}{*}{ Panel B: with controls } & \multicolumn{3}{|c|}{ Public schools } & \multicolumn{3}{|c|}{ Private schools } \\
\hline & $(1)$ & $(2)$ & (3) & $(4)$ & $(5)$ & $(6)$ \\
\hline & \multicolumn{6}{|c|}{ Dependent variable: teacher practice index } \\
\hline z-management & $\begin{array}{c}0.260^{* * *} \\
(0.061)\end{array}$ & & & $\begin{array}{c}0.189^{* * *} \\
(0.059)\end{array}$ & & \\
\hline z-operations & & $\begin{array}{r}0.218^{* * *} \\
(0.049)\end{array}$ & & & $\begin{array}{c}0.168^{* * *} \\
(0.052)\end{array}$ & \\
\hline z-people & & & $\begin{array}{c}0.259^{* *} \\
(0.112)\end{array}$ & & & $\begin{array}{c}0.238^{* *} \\
(0.097)\end{array}$ \\
\hline Observations & 740 & 740 & 740 & 1367 & 1367 & 1367 \\
\hline \# schools & 109 & 109 & 109 & 190 & 190 & 190 \\
\hline Outcome variable SD & 0.89 & 0.89 & 0.89 & 1.06 & 1.06 & 1.06 \\
\hline
\end{tabular}

Notes: Standard errors are clustered by school. Teacher practice index is an index of two audited indicators (whether the teacher was present and whether the teacher was actively teaching at the time of the audit), and fourteen self-reported classroom practices. The fourteen practices include: makes lesson plans, has textbook/workbook, checks hygiene daily, $\%$ time teaching, $\%$ time on teaching activities, $\%$ time "on task", and a series of indicators if the teacher spends above average time on a set of remedial class activities (remedial attention in class, outside class, helping arrange private tuition, helping at home, and other type of help). The teacher practice index is a standardized measure, built using the Anderson (2008) weighted average method. z-management is the standardized overall management index. z-operations and z-people are the standardized average scores of the operations questions and people management questions. Controls include those listed in Table 2: teacher controls (share of teachers with a degree, share with teacher training, average teaching experience, average number of work days, head teacher teaching experience and head teacher education) and school controls (log of number of students, average share of female students, of students from scheduled castes, of literate parents and of laborer parents). Includes subject and year fixed effects. 
Table 4: School management practices and student value added in each type of school

\begin{tabular}{|c|c|c|c|c|c|c|c|c|}
\hline \multirow[t]{2}{*}{ Panel A: No controls } & \multicolumn{4}{|c|}{ Public schools } & \multicolumn{4}{|c|}{ Private schools } \\
\hline & $\begin{array}{c}(1) \\
\text { student } \\
\text { value added }\end{array}$ & $\begin{array}{c}(2) \\
\text { student } \\
\text { value added }\end{array}$ & $\begin{array}{c}(3) \\
\text { student } \\
\text { value added }\end{array}$ & $\begin{array}{c}(4) \\
\text { student } \\
\text { value added }\end{array}$ & $\begin{array}{c}(5) \\
\text { student } \\
\text { value added }\end{array}$ & $\begin{array}{c}(6) \\
\text { student } \\
\text { value added }\end{array}$ & $\begin{array}{c}(7) \\
\text { student } \\
\text { value added }\end{array}$ & $\begin{array}{c}(8) \\
\text { student } \\
\text { value added }\end{array}$ \\
\hline z-management & $\begin{array}{c}0.181 * * * \\
(0.036)\end{array}$ & & & & $\begin{array}{c}0.044 \\
(0.0283)\end{array}$ & & & \\
\hline z-operations & & $\begin{array}{c}0.142^{* * *} \\
(0.032)\end{array}$ & & $\begin{array}{c}0.077^{*} \\
(0.040)\end{array}$ & & $\begin{array}{c}0.030 \\
(0.026)\end{array}$ & & $\begin{array}{l}-0.017 \\
(0.035)\end{array}$ \\
\hline z-people & & & $\begin{array}{c}0.381^{* * *} \\
(0.069)\end{array}$ & $\begin{array}{c}0.265^{* * *} \\
(0.089)\end{array}$ & & & $\begin{array}{c}0.103^{* *} \\
(0.041)\end{array}$ & $\begin{array}{c}0.123^{* *} \\
(0.057)\end{array}$ \\
\hline Observations & 7157 & 7157 & 7157 & 7157 & 28807 & 28807 & 28807 & 28807 \\
\hline \# schools & 109 & 109 & 109 & 109 & 190 & 190 & 190 & 190 \\
\hline \multirow[t]{2}{*}{ Panel B: with controls } & \multicolumn{4}{|c|}{ Public schools } & \multicolumn{4}{|c|}{ Private schools } \\
\hline & $\begin{array}{c}\text { (1) } \\
\text { student } \\
\text { value added }\end{array}$ & $\begin{array}{c}(2) \\
\text { student } \\
\text { value added }\end{array}$ & $\begin{array}{c}(3) \\
\text { student } \\
\text { value added }\end{array}$ & $\begin{array}{c}(4) \\
\text { student } \\
\text { value added }\end{array}$ & $\begin{array}{c}(5) \\
\text { student } \\
\text { value added }\end{array}$ & $\begin{array}{c}(6) \\
\text { student } \\
\text { value added }\end{array}$ & $\begin{array}{c}(7) \\
\text { student } \\
\text { value added }\end{array}$ & $\begin{array}{c}(8) \\
\text { student } \\
\text { value added }\end{array}$ \\
\hline z-management & $\begin{array}{c}0.169^{* * *} \\
(0.044)\end{array}$ & & & & $\begin{array}{c}0.044 \\
(0.0277)\end{array}$ & & & \\
\hline z-operations & & $\begin{array}{c}0.130^{* * *} \\
(0.037)\end{array}$ & & $\begin{array}{c}0.081^{* *} \\
(0.039)\end{array}$ & & $\begin{array}{c}0.024 \\
(0.025)\end{array}$ & & $\begin{array}{l}-0.029 \\
(0.034)\end{array}$ \\
\hline z-people & & & $\begin{array}{c}0.336^{* * *} \\
(0.087)\end{array}$ & $\begin{array}{c}0.225^{* *} \\
(0.096)\end{array}$ & & & $\begin{array}{c}0.127^{* * *} \\
(0.042)\end{array}$ & $\begin{array}{c}0.156^{* * *} \\
(0.056)\end{array}$ \\
\hline Observations & 7157 & 7157 & 7157 & 7157 & 28807 & 28807 & 28807 & 28807 \\
\hline \# schools & 109 & 109 & 109 & 109 & 190 & 190 & 190 & 190 \\
\hline
\end{tabular}


Table 5: School management practices and student value added in public and private schools

\begin{tabular}{|c|c|c|c|c|c|}
\hline \multirow[t]{2}{*}{ Panel A: no controls } & \multicolumn{5}{|c|}{ Public and private schools } \\
\hline & $\begin{array}{c}(1) \\
\text { student } \\
\text { value added }\end{array}$ & $\begin{array}{c}(2) \\
\text { student } \\
\text { value added }\end{array}$ & $\begin{array}{c}(3) \\
\text { student } \\
\text { value added }\end{array}$ & $\begin{array}{c}(4) \\
\text { student } \\
\text { value added }\end{array}$ & $\begin{array}{c}(5) \\
\text { student } \\
\text { value added }\end{array}$ \\
\hline Private $=1$ & $\begin{array}{c}0.348^{* * *} \\
(0.057)\end{array}$ & $\begin{array}{c}0.250^{* * * *} \\
(0.059)\end{array}$ & $\begin{array}{c}0.311^{* * *} \\
(0.054)\end{array}$ & $\begin{array}{c}0.059 \\
(0.083)\end{array}$ & $\begin{array}{c}0.101 \\
(0.098)\end{array}$ \\
\hline Scholarship = 1 & $\begin{array}{c}-0.234^{* * *} \\
(0.076)\end{array}$ & $\begin{array}{c}-0.245^{* * *} \\
(0.077)\end{array}$ & $\begin{array}{c}-0.239 * * * \\
(0.078)\end{array}$ & $\begin{array}{c}-0.262^{* * *} \\
(0.073)\end{array}$ & $\begin{array}{c}-0.258^{* * *} \\
(0.074)\end{array}$ \\
\hline z-management & & $\begin{array}{c}0.089^{* * * *} \\
(0.024)\end{array}$ & & & \\
\hline z-operations & & & $\begin{array}{c}0.070^{* * *} \\
(0.022)\end{array}$ & & $\begin{array}{c}0.026 \\
(0.030)\end{array}$ \\
\hline z-people & & & & $\begin{array}{c}0.160^{* * *} \\
(0.036)\end{array}$ & $\begin{array}{c}0.129 * * \\
(0.050)\end{array}$ \\
\hline Observations & 35964 & 35964 & 35964 & 35964 & 35964 \\
\hline \# schools & 299 & 299 & 299 & 299 & 299 \\
\hline \multirow[t]{2}{*}{ Panel B: with controls } & \multicolumn{5}{|c|}{ Public and private schools } \\
\hline & $\begin{array}{c}\text { (1) } \\
\text { student } \\
\text { value added }\end{array}$ & $\begin{array}{c}(2) \\
\text { student } \\
\text { value added }\end{array}$ & $\begin{array}{c}(3) \\
\text { student } \\
\text { value added }\end{array}$ & $\begin{array}{c}(4) \\
\text { student } \\
\text { value added }\end{array}$ & $\begin{array}{c}(5) \\
\text { student } \\
\text { value added }\end{array}$ \\
\hline Private $=1$ & $\begin{array}{c}0.490^{* * *} \\
(0.086)\end{array}$ & $\begin{array}{c}0.395^{* * *} \\
(0.086)\end{array}$ & $\begin{array}{c}0.455^{* * *} \\
(0.084)\end{array}$ & $\begin{array}{c}0.203^{* *} \\
(0.098)\end{array}$ & $\begin{array}{c}0.233^{* *} \\
(0.106)\end{array}$ \\
\hline Scholarship = 1 & $\begin{array}{c}-0.242^{* * *} \\
(0.074)\end{array}$ & $\begin{array}{c}-0.258^{* * *} \\
(0.073)\end{array}$ & $\begin{array}{c}-0.252^{* * *} \\
(0.074)\end{array}$ & $\begin{array}{c}-0.273^{* * *} \\
(0.070)\end{array}$ & $\begin{array}{c}-0.272^{* * *} \\
(0.071)\end{array}$ \\
\hline z-management & & $\begin{array}{c}0.090^{* * *} \\
(0.025)\end{array}$ & & & \\
\hline z-operations & & & $\begin{array}{c}0.068^{* * *} \\
(0.022)\end{array}$ & & $\begin{array}{c}0.022 \\
(0.028)\end{array}$ \\
\hline z-people & & & & $\begin{array}{c}0.166^{* * *} \\
(0.036)\end{array}$ & $\begin{array}{c}0.142^{* * * *} \\
(0.046)\end{array}$ \\
\hline Observations & 35964 & 35964 & 35964 & 35964 & 35964 \\
\hline \# schools & 299 & 299 & 299 & 299 & 299 \\
\hline
\end{tabular}

Notes: Standard errors are clustered by school. The dependent variable student value added is estimated by using the residuals of a regression of the end-line test score on the baseline test score for each student. z-management is the standardized overall management index. z-operations and z-people are the standardized average scores of the operations questions and people management questions. Private refers to an indicator for private school, and scholarship is an indicator for whether the student received a scholarship in the Muralidharan and Sundararaman (2015) school choice experiment. Controls include those listed in Table 2: student controls (indicators for female student, scheduled caste, parents are literate, parents are manual laborers, and a household assets index), teacher controls (share of teachers with a degree, share with teacher training, average teaching experience, average number of work days, head teacher teaching experience and head teacher education) and school controls (log of number of students, average share of female students, of students from scheduled castes, of literate parents and of laborer parents). Includes subject and year fixed effects. 
Table 6: School management practices and teacher wages

\begin{tabular}{|c|c|c|c|c|c|c|c|}
\hline \multirow[t]{2}{*}{ Panel A: No controls } & \multicolumn{3}{|c|}{ Public } & \multicolumn{3}{|c|}{ Private } & \multirow{2}{*}{$\frac{\text { All }}{(7)}$} \\
\hline & $\begin{array}{c}(1) \\
\ln (\text { wages })\end{array}$ & $\begin{array}{c}(2) \\
\ln (\text { wages })\end{array}$ & $\begin{array}{c}(3) \\
\ln (\text { wages })\end{array}$ & $\begin{array}{c}(4) \\
\ln (\text { wages })\end{array}$ & $\begin{array}{c}(5) \\
\ln (\text { wages })\end{array}$ & $\begin{array}{c}(6) \\
\ln (\text { wages })\end{array}$ & \\
\hline \multicolumn{8}{|l|}{ Value added } \\
\hline Teacher value added & $\begin{array}{l}-0.227 \\
(0.222)\end{array}$ & $\begin{array}{l}-0.218 \\
(0.222)\end{array}$ & $\begin{array}{l}-0.124 \\
(0.235)\end{array}$ & $\begin{array}{c}0.424^{* * *} \\
(0.119)\end{array}$ & $\begin{array}{c}0.353^{* * *} \\
(0.117)\end{array}$ & $\begin{array}{c}0.378^{* * *} \\
(0.118)\end{array}$ & $\begin{array}{l}-0.217 \\
(0.230)\end{array}$ \\
\hline Private $=1$ & & & & & & & $\begin{array}{c}-1.912^{* * *} \\
(0.049)\end{array}$ \\
\hline Private $=1 \times \mathrm{TVA}$ & & & & & & & $\begin{array}{c}0.681^{* * * *} \\
(0.260)\end{array}$ \\
\hline \multicolumn{8}{|l|}{ Management } \\
\hline z-operations & & $\begin{array}{l}-0.005 \\
(0.032)\end{array}$ & & & $\begin{array}{c}0.101^{* * *} \\
(0.031)\end{array}$ & & \\
\hline z-people & & & $\begin{array}{l}-0.154 \\
(0.115) \\
\end{array}$ & & & $\begin{array}{c}0.125 * * \\
(0.063) \\
\end{array}$ & \\
\hline \# Teachers & 234 & 234 & 234 & 1059 & 1059 & 1059 & 1245 \\
\hline \# Schools & 104 & 104 & 104 & 190 & 190 & 190 & 277 \\
\hline Mean wages (Rs) & 14097 & 14097 & 14097 & 2655 & 2655 & 2655 & 6334 \\
\hline \multirow[t]{3}{*}{ Panel B: with controls } & \multicolumn{3}{|c|}{ Public } & \multicolumn{3}{|c|}{ Private } & All \\
\hline & (1) & (2) & $(3)$ & (4) & $(5)$ & (6) & (7) \\
\hline & $\ln$ (wages) & $\ln$ (wages) & $\ln$ (wages) & $\ln$ (wages) & $\ln$ (wages) & $\ln$ (wages) & $\ln$ (wages) \\
\hline \multicolumn{8}{|l|}{ Value added } \\
\hline Teacher value added & $\begin{array}{l}-0.285 \\
(0.197)\end{array}$ & $\begin{array}{l}-0.289 \\
(0.197)\end{array}$ & $\begin{array}{l}-0.272 \\
(0.205)\end{array}$ & $\begin{array}{c}0.258^{* *} \\
(0.102)\end{array}$ & $\begin{array}{c}0.246^{* *} \\
(0.101)\end{array}$ & $\begin{array}{c}0.257^{* *} \\
(0.102)\end{array}$ & $\begin{array}{l}-0.267 \\
(0.207)\end{array}$ \\
\hline Private $=1$ & & & & & & & $\begin{array}{c}-1.522^{* * *} \\
(0.078)\end{array}$ \\
\hline Private $=1 \times$ TVA & & & & & & & $\begin{array}{c}0.538^{* *} \\
(0.228)\end{array}$ \\
\hline \multicolumn{8}{|l|}{ Management } \\
\hline z-operations & & $\begin{array}{c}0.002 \\
(0.026)\end{array}$ & & & $\begin{array}{c}0.028 \\
(0.027)\end{array}$ & & \\
\hline z-people & & & $\begin{array}{l}-0.025 \\
(0.096)\end{array}$ & & & $\begin{array}{c}0.003 \\
(0.049)\end{array}$ & \\
\hline \# Teachers & 227 & 227 & 227 & 1018 & 1018 & 1018 & 1245 \\
\hline \# Schools & 99 & 99 & 99 & 178 & 178 & 178 & 277 \\
\hline Mean wages (Rs) & 14097 & 14097 & 14097 & 2655 & 2655 & 2655 & 6334 \\
\hline
\end{tabular}

Notes: Standard errors are clustered by school. Teacher value added is estimated using the Chetty et al. (2014) method and vam Stata command. Private refers to an indicator for private school. Private x TVA is an interaction between the private indicator and the teacher value added measure. z-operations and z-people are the standardized average scores of the operations questions and people management questions. Controls include those listed in Table 2: teacher controls (share of teachers with a degree, share with teacher training, average teaching experience, average number of work days, head teacher teaching experience and head teacher education) and school controls (log of number of students, average share of female students, of students from scheduled castes, of literate parents and of laborer parents). Data is collapsed across all years of data to build teacher averages. 
Table 7: School management practices and teacher flows

\begin{tabular}{|c|c|c|c|c|c|}
\hline \multirow{2}{*}{$\begin{array}{l}\text { Panel A: no controls } \\
\text { Dependent variable: } \\
\text { good HR outcome }\end{array}$} & \multirow{2}{*}{$\begin{array}{l}\text { All } \\
(1)\end{array}$} & \multicolumn{2}{|c|}{ Public } & \multicolumn{2}{|c|}{ Private } \\
\hline & & $(2)$ & $(3)$ & $(4)$ & $(5)$ \\
\hline Private $=1$ & $\begin{array}{c}-0.213^{* * *} \\
(0.043)\end{array}$ & & & & \\
\hline $\begin{array}{l}\text { Management } \\
\text { z-operations }\end{array}$ & & $\begin{array}{r}-0.009 * \\
(0.004)\end{array}$ & & $\begin{array}{c}0.039^{* *} \\
(0.014)\end{array}$ & \\
\hline z-people & & & $\begin{array}{c}0.001 \\
(0.009)\end{array}$ & & $\begin{array}{c}0.058 * * \\
(0.015)\end{array}$ \\
\hline \# Teachers & 543 & 53 & 53 & 490 & 490 \\
\hline Panel B: with controls & All & \multicolumn{2}{|c|}{ Public } & \multicolumn{2}{|c|}{ Private } \\
\hline $\begin{array}{l}\text { Dependent variable: } \\
\text { good HR outcome }\end{array}$ & (1) & $(2)$ & $(3)$ & $(4)$ & $(5)$ \\
\hline Private $=1$ & $\begin{array}{c}-0.214^{* * *} \\
(0.038)\end{array}$ & & & & \\
\hline $\begin{array}{l}\text { Management } \\
\text { z-operations }\end{array}$ & & $\begin{array}{l}-0.013 \\
(0.009)\end{array}$ & & $\begin{array}{c}0.031 \\
(0.015)\end{array}$ & \\
\hline z-people & & & $\begin{array}{l}-0.015 \\
(0.021)\end{array}$ & & $\begin{array}{l}0.046^{* *} \\
(0.015)\end{array}$ \\
\hline \# Teachers & 514 & 51 & 51 & 463 & 463 \\
\hline
\end{tabular}

Notes: Standard errors are clustered by school. The sample uses only schools which had data about teacher transfers during year 2 of the Muralidharan and Sundararaman (2015) experiment (2009). The dependent variable, "good HR outcome", is a binary outcome. It takes a value of 1 if a high value added teacher was transferred in or retained in the school, or if a low value added teacher is transferred out of the school. It takes a value of 0 otherwise. Teacher value added is estimated using the Chetty et al. (2014) method and vam Stata command. A teacher is coded as "high value added" when their year 1 value added is the highest within their school. A teacher is coded as "low value added" when their year 1 value added is the lowest within their school. Private refers to an indicator for private school. z-operations and z-people are the standardized average scores of the operations questions and people management questions. Controls include school controls listed in Table 2: $\log$ of number of students, average share of female students, of students from scheduled castes, of literate parents and of laborer parents. 


\section{ONLINE APPENDIX}

"Personnel Management and School Productivity: Evidence from India," July 8, 2021

\section{A Additional figures and tables}


Figure A1: Global benchmarks

(a) Rank of comparable people management z-scores

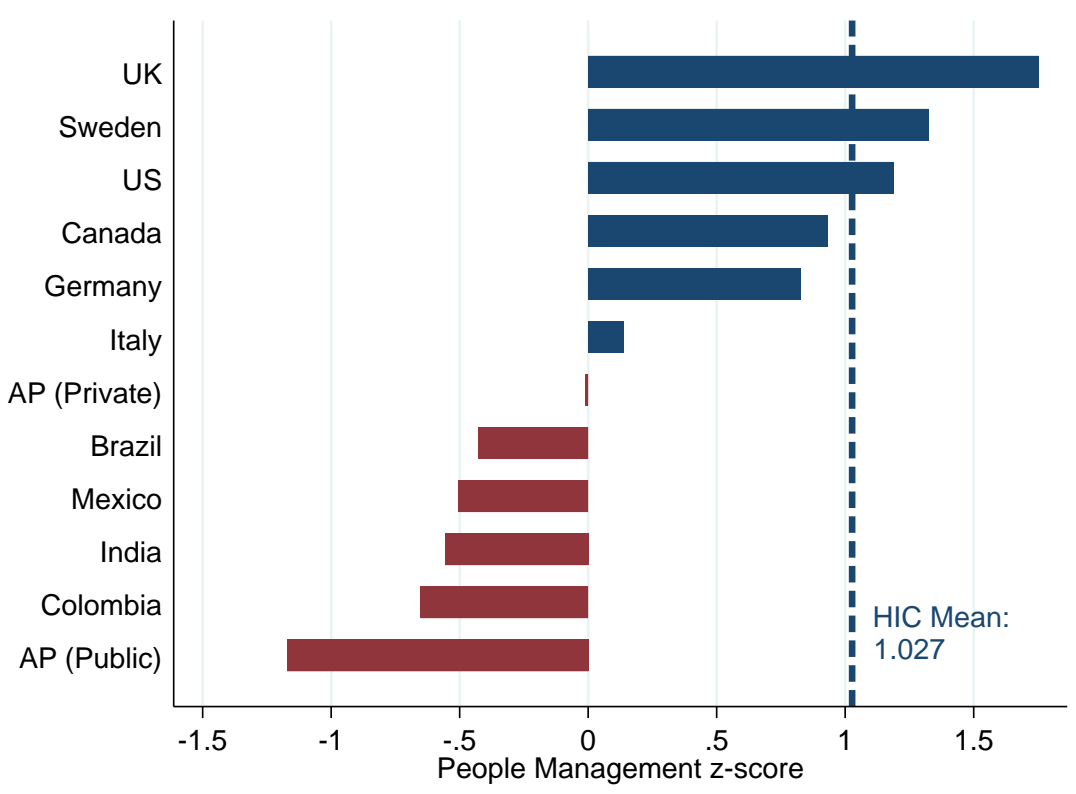

(b) Comparable management z-scores and GDP per capita

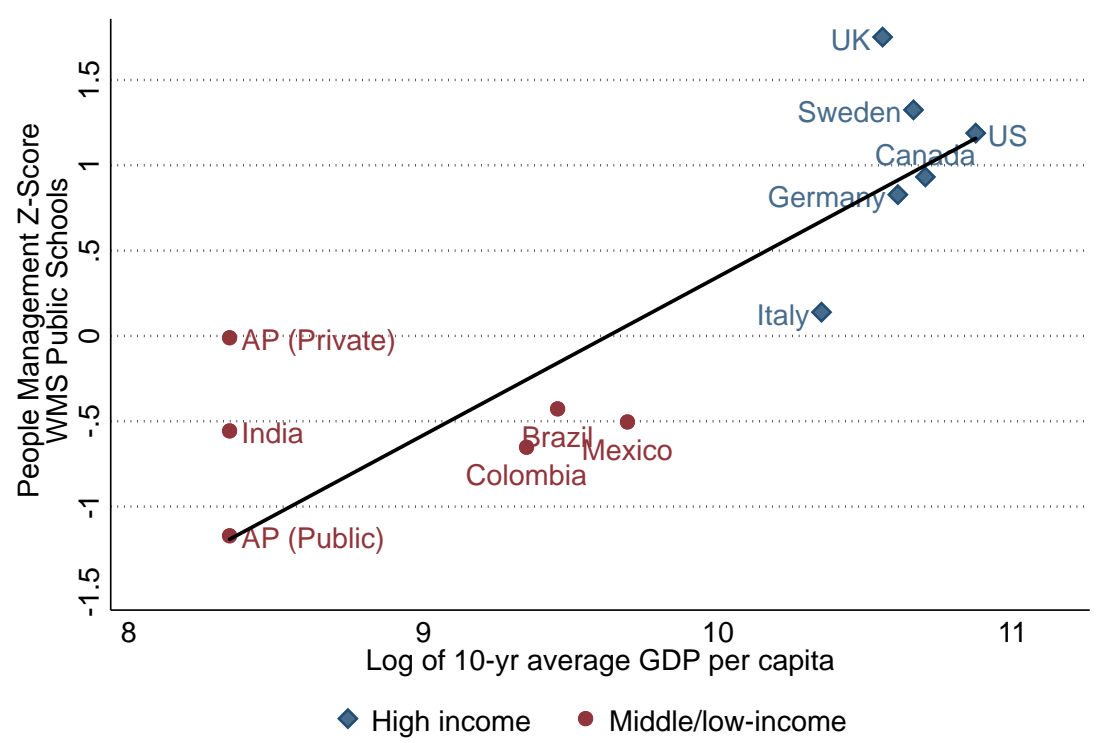

Note: This figure includes only public secondary schools from the WMS dataset (UK, Canada, Sweden, US, Germany, Italy, Brazil and India) and public primary schools from the Development WMS dataset (Andhra Pradesh, Mexico and Colombia). The Development WMS scores were re-scaled to match the WMS scoring convention: all half points were downgraded to the next lowest whole point for each survey question (for example, all scores of 2.5 were re-cast to 2 ) before indices were built. Data for the WMS for all countries except for Mexico and Colombia can be found at www.worldmanagementsurvey.org. Distribution of overall management indices standardized within countries. Country averages for all other countries were estimated using sampling weights (see Appendix B for details on the weights construction). Number of WMS observations are as follows: Brazil $=373$, Canada $=113$, Colombia $=447$, Great Britain $=78$, Germany $=91$, India $=130$, Italy $=222$, Mexico $=178$, Sweden $=85$, United States $=193$. The 10-year average GDP per capita comes from Aqp India's GDP as a stand-in for Andhra Pradesh's GPD in Panel (b). 
Figure A2: Difference between across public and private: India vs OECD

(a) Operations management

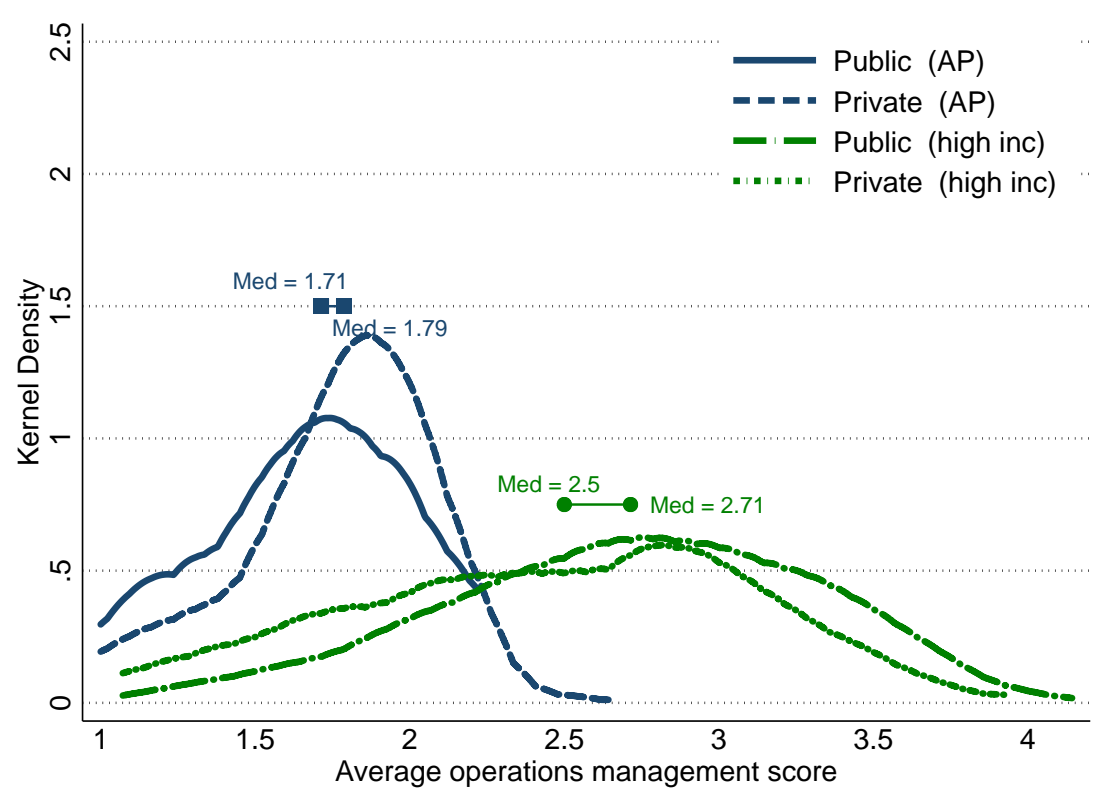

(b) People management

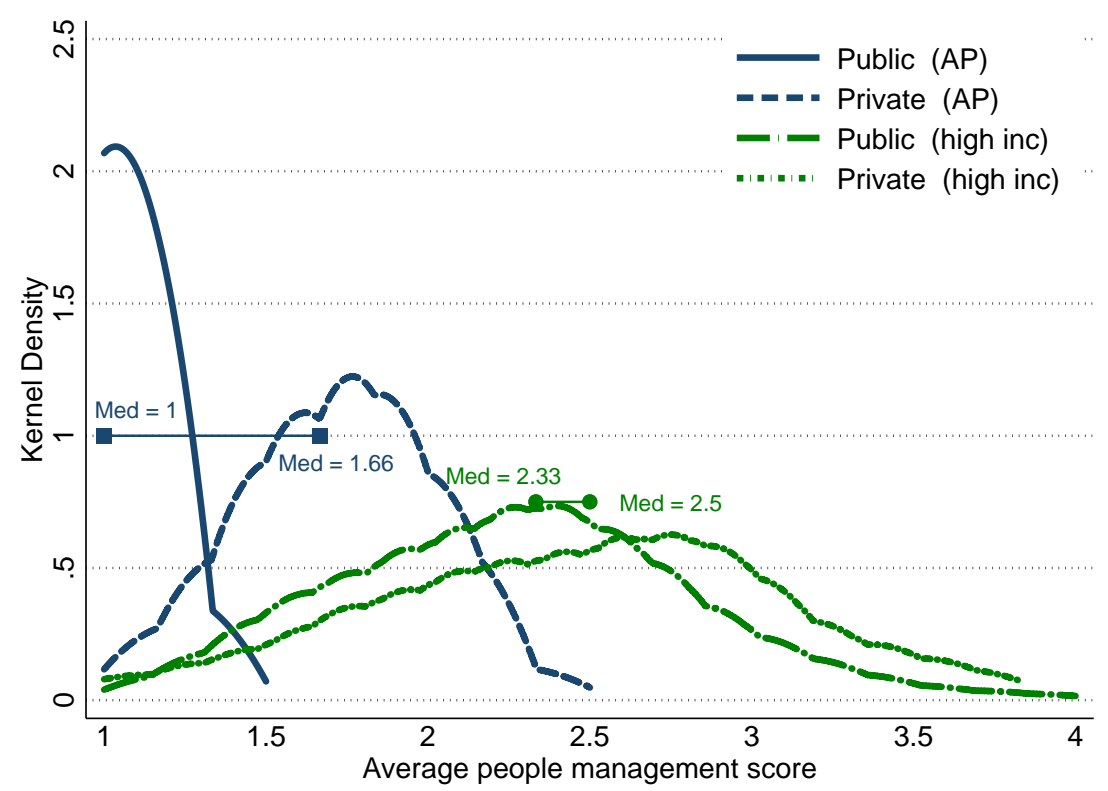

Note: This figure includes only public secondary schools from the WMS dataset (UK, Canada, Sweden, US, Germany, Italy) and public primary schools from the Development WMS dataset (Andhra Pradesh). The Development WMS scores were re-scaled to match the WMS scoring convention: all half points were downgraded to the next lowest whole point for each survey question (for example, all scores of 2.5 were re-cast to 2) before indices were built. Data for the WMS for all high income countries can be found at www.worldmanagementsurvey.org. Country averages for WMS countries were estimated using sampling weights (see Appendix B for details on the weights construction). Number of WMS observations are as follows: Brazil $=510$, Canada $=129$, Colombia $=468$, Great Britain $=89$, Germany $=102$, Italy $=284$, Mexico $=157$, Sweden $=85$, United States $=263$. Number of AP observations $=300$. Squares mark the median point of the AP distributions, and circles mark the median points of the high-income countries distribution.

App. 3 
Table A1: Public and private schools are different on observables

\begin{tabular}{|c|c|c|c|c|}
\hline & $\begin{array}{c}(1) \\
\text { Private } \\
\text { schools }\end{array}$ & $\begin{array}{c}(2) \\
\text { Public } \\
\text { schools }\end{array}$ & $\begin{array}{c}\text { (3) } \\
\text { Difference }\end{array}$ & $\begin{array}{c}(4) \\
\text { Table } \\
\text { reference }\end{array}$ \\
\hline \multicolumn{5}{|l|}{ Panel A: School characteristics } \\
\hline Total enrollment & 296.21 & 74.04 & $222.17^{* * *}$ & Table 3 \\
\hline Total working days & 229.81 & 218.66 & $11.15^{* * *}$ & Table 3 \\
\hline Pupil-teacher ratio & 17.62 & 25.28 & $-7.67 * * *$ & Table 3 \\
\hline Observations & 289 & 346 & & \\
\hline Annual cost per child (Rs/child) & $1,848.88$ & $8,390.00$ & $-6,542^{* * *}$ & Table 3 \\
\hline Observations & 211 & 325 & & \\
\hline Student time spent in school (minutes) & 423.53 & 380.25 & $43.28 * * *$ & Table 4 \\
\hline Observations & 652 & 1,839 & & \\
\hline Multi-grade teaching & 0.24 & 0.79 & $-0.55 * * *$ & Table 5 \\
\hline Observations & 2,738 & 2,784 & & \\
\hline \multicolumn{5}{|l|}{ Panel B: Teacher characteristics } \\
\hline Male & 0.24 & 0.46 & $-0.21^{* * *}$ & Table 3 \\
\hline Age & 27.58 & 40.00 & $-12.42^{* * *}$ & Table 3 \\
\hline Years of teaching & 5.14 & 14.96 & $-9.82^{* * *}$ & Table 3 \\
\hline Completed at least college or masters & 0.69 & 0.88 & $-0.19 * * *$ & Table 3 \\
\hline Teacher training completed & 0.34 & 0.99 & $-0.65^{* * *}$ & Table 3 \\
\hline Come from the same village & 0.44 & 0.13 & $0.32^{* * *}$ & Table 3 \\
\hline Current gross salary per month (Rs) & $2,606.66$ & $14,285.94$ & $-11,679.27^{* * *}$ & Table 3 \\
\hline Observations & 2,000 & 1,358 & & \\
\hline Teacher is absent & 0.09 & 0.24 & $-0.15^{* * *}$ & Table 4 \\
\hline Teacher is actively teaching & 0.50 & 0.35 & $0.15^{* * *}$ & Table 4 \\
\hline Observations & 6,577 & 5,552 & & \\
\hline
\end{tabular}

Notes: Table reproduced from Muralidharan and Sundararaman (2015), Tables 3, 4 and 5. 
Table A2: Correlates of management quality: teacher and student observables

\begin{tabular}{|c|c|c|c|c|c|c|}
\hline & \multicolumn{3}{|c|}{ Public } & \multicolumn{3}{|c|}{ Private } \\
\hline & $\begin{array}{c}(1) \\
\text { z-mgmt }\end{array}$ & $\begin{array}{c}(2) \\
\text { Z-ops }\end{array}$ & $\begin{array}{c}(3) \\
\text { z-people }\end{array}$ & $\begin{array}{c}(4) \\
\text { z-mgmt }\end{array}$ & $\begin{array}{c}(5) \\
\text { Z-ops }\end{array}$ & $\begin{array}{c}(6) \\
\text { z-people }\end{array}$ \\
\hline \multicolumn{7}{|l|}{ Student characteristics } \\
\hline Share female & $\begin{array}{c}0.246 \\
(0.696)\end{array}$ & $\begin{array}{c}0.301 \\
(0.840)\end{array}$ & $\begin{array}{c}0.062 \\
(0.373)\end{array}$ & $\begin{array}{l}-0.318 \\
(0.834)\end{array}$ & $\begin{array}{l}-0.259 \\
(0.899)\end{array}$ & $\begin{array}{l}-0.324 \\
(0.536)\end{array}$ \\
\hline Share scheduled caste & $\begin{array}{c}0.156 \\
(0.414)\end{array}$ & $\begin{array}{c}0.225 \\
(0.518)\end{array}$ & $\begin{array}{l}-0.024 \\
(0.197)\end{array}$ & $\begin{array}{c}3.405^{* * *} \\
(0.749)\end{array}$ & $\begin{array}{c}3.526^{* * *} \\
(0.813)\end{array}$ & $\begin{array}{c}2.043^{* * *} * \\
(0.513)\end{array}$ \\
\hline Share literate parents & $\begin{array}{c}0.968^{* *} \\
(0.455)\end{array}$ & $\begin{array}{l}1.145^{* *} \\
(0.555)\end{array}$ & $\begin{array}{c}0.315 \\
(0.219)\end{array}$ & $\begin{array}{c}-0.793 \\
(0.646)\end{array}$ & $\begin{array}{c}-0.920 \\
(0.698)\end{array}$ & $\begin{array}{l}-0.291 \\
(0.404)\end{array}$ \\
\hline Share laborer parents & $\begin{array}{c}-1.379 * * * \\
(0.456)\end{array}$ & $\begin{array}{c}-1.592^{* * *} \\
(0.565)\end{array}$ & $\begin{array}{c}-0.522 * * \\
(0.231)\end{array}$ & $\begin{array}{l}-1.446^{*} \\
(0.750)\end{array}$ & $\begin{array}{l}-1.470^{*} \\
(0.834)\end{array}$ & $\begin{array}{c}-0.917^{* *} \\
(0.427)\end{array}$ \\
\hline Average household assets index & $\begin{array}{l}-0.264 \\
(0.261)\end{array}$ & $\begin{array}{l}-0.290 \\
(0.319)\end{array}$ & $\begin{array}{l}-0.127 \\
(0.111)\end{array}$ & $\begin{array}{c}0.342 \\
(0.307)\end{array}$ & $\begin{array}{c}0.376 \\
(0.333)\end{array}$ & $\begin{array}{c}0.164 \\
(0.201)\end{array}$ \\
\hline Teacher characteristics & & & & & & \\
\hline Share with a degree & $\begin{array}{c}1.133^{* *} \\
(0.566)\end{array}$ & $\begin{array}{l}1.330^{*} \\
(0.678)\end{array}$ & $\begin{array}{c}0.387 \\
(0.307)\end{array}$ & $\begin{array}{c}0.310 \\
(0.236)\end{array}$ & $\begin{array}{c}0.344 \\
(0.261)\end{array}$ & $\begin{array}{c}0.142 \\
(0.150)\end{array}$ \\
\hline Share with teacher training & $\begin{array}{c}0.070 \\
(0.543)\end{array}$ & $\begin{array}{l}-0.002 \\
(0.671)\end{array}$ & $\begin{array}{c}0.182 \\
(0.203)\end{array}$ & $\begin{array}{c}0.160 \\
(0.203)\end{array}$ & $\begin{array}{c}0.180 \\
(0.222)\end{array}$ & $\begin{array}{c}0.069 \\
(0.133)\end{array}$ \\
\hline Average teaching experience & $\begin{array}{l}-0.009 \\
(0.035)\end{array}$ & $\begin{array}{l}-0.005 \\
(0.042)\end{array}$ & $\begin{array}{l}-0.015 \\
(0.017)\end{array}$ & $\begin{array}{l}-0.015 \\
(0.032)\end{array}$ & $\begin{array}{l}-0.014 \\
(0.037)\end{array}$ & $\begin{array}{l}-0.013 \\
(0.015)\end{array}$ \\
\hline Average \# workdays & $\begin{array}{l}-0.008 \\
(0.009)\end{array}$ & $\begin{array}{l}-0.011 \\
(0.011)\end{array}$ & $\begin{array}{l}-0.000 \\
(0.004)\end{array}$ & $\begin{array}{c}0.003 \\
(0.006)\end{array}$ & $\begin{array}{c}0.003 \\
(0.006)\end{array}$ & $\begin{array}{c}0.002 \\
(0.003)\end{array}$ \\
\hline Head teacher teaching experience & $\begin{array}{c}0.031 \\
(0.041)\end{array}$ & $\begin{array}{c}0.035 \\
(0.050)\end{array}$ & $\begin{array}{c}0.012 \\
(0.019)\end{array}$ & $\begin{array}{c}0.020 \\
(0.037)\end{array}$ & $\begin{array}{c}0.018 \\
(0.041)\end{array}$ & $\begin{array}{c}0.019 \\
(0.022)\end{array}$ \\
\hline Head teacher has degree & $\begin{array}{c}-1.042^{* *} \\
(0.515)\end{array}$ & $\begin{array}{c}-1.269^{* *} \\
(0.621)\end{array}$ & $\begin{array}{l}-0.271 \\
(0.260)\end{array}$ & $\begin{array}{c}0.557 \\
(0.368)\end{array}$ & $\begin{array}{c}0.582 \\
(0.398)\end{array}$ & $\begin{array}{c}0.325 \\
(0.235)\end{array}$ \\
\hline $\begin{array}{l}\text { School characteristics } \\
\text { School size (\# students) }\end{array}$ & $\begin{array}{l}-0.246 \\
(0.156)\end{array}$ & $\begin{array}{l}-0.271 \\
(0.190)\end{array}$ & $\begin{array}{l}-0.118 \\
(0.075)\end{array}$ & $\begin{array}{c}0.337^{* * *} \\
(0.079)\end{array}$ & $\begin{array}{c}0.340^{* * *} \\
(0.086)\end{array}$ & $\begin{array}{c}0.219^{* * *} \\
(0.053)\end{array}$ \\
\hline
\end{tabular}

Notes: Standard errors are clustered by school. z-mgmt is the overall standardized management score. z-ops is the standardized index of operations questions and z-people is the standardized index of people management questions. Headteacher refers to the teacher formally appointed as headteacher or the most senior teacher at the school. 
Table A3: Residualized school management practices and student value added

\begin{tabular}{|c|c|c|c|c|}
\hline & \multicolumn{4}{|c|}{ Public schools } \\
\hline & $\begin{array}{c}(1) \\
\text { student } \\
\text { value added }\end{array}$ & $\begin{array}{c}(2) \\
\text { student } \\
\text { value added }\end{array}$ & $\begin{array}{c}(3) \\
\text { student } \\
\text { value added }\end{array}$ & $\begin{array}{c}(4) \\
\text { student } \\
\text { value added }\end{array}$ \\
\hline z-management (residual) & $\begin{array}{c}0.168^{* * *} \\
(0.047)\end{array}$ & & & \\
\hline z-operations (residual) & & $\begin{array}{c}0.130^{* * *} \\
(0.040)\end{array}$ & & $\begin{array}{l}0.080^{*} \\
(0.046)\end{array}$ \\
\hline z-people (residual) & & & $\begin{array}{c}0.334^{* * * *} \\
(0.096)\end{array}$ & $\begin{array}{c}0.224^{* *} \\
(0.107)\end{array}$ \\
\hline \multirow{4}{*}{$\begin{array}{l}\text { Observations } \\
\text { \# schools }\end{array}$} & 7157 & 7157 & 7157 & 7157 \\
\hline & 109 & 109 & 109 & 109 \\
\hline & \multicolumn{4}{|c|}{ Private schools } \\
\hline & $\begin{array}{c}(1) \\
\text { student } \\
\text { value added }\end{array}$ & $\begin{array}{c}(2) \\
\text { student } \\
\text { value added }\end{array}$ & $\begin{array}{c}(3) \\
\text { student } \\
\text { value added }\end{array}$ & $\begin{array}{c}(4) \\
\text { student } \\
\text { value added }\end{array}$ \\
\hline z-management (residual) & $\begin{array}{c}0.046 \\
(0.034)\end{array}$ & & & \\
\hline z-operations (residual) & & $\begin{array}{c}0.026 \\
(0.030)\end{array}$ & & $\begin{array}{c}-0.026 \\
(0.040)\end{array}$ \\
\hline z-people (residual) & & & $\begin{array}{c}0.127 * * \\
(0.052)\end{array}$ & $\begin{array}{c}0.154^{* *} \\
(0.066)\end{array}$ \\
\hline \multirow{4}{*}{$\begin{array}{l}\text { Observations } \\
\text { \# schools }\end{array}$} & 28807 & 28807 & 28807 & 28807 \\
\hline & 190 & 190 & 190 & 190 \\
\hline & \multicolumn{4}{|c|}{ Public and private schools } \\
\hline & $\begin{array}{c}(1) \\
\text { student } \\
\text { value added }\end{array}$ & $\begin{array}{c}(2) \\
\text { student } \\
\text { value added }\end{array}$ & $\begin{array}{c}(3) \\
\text { student } \\
\text { value added }\end{array}$ & $\begin{array}{c}(4) \\
\text { student } \\
\text { value added }\end{array}$ \\
\hline Private (residual) & $\begin{array}{c}0.414^{* * *} \\
(0.089)\end{array}$ & $\begin{array}{c}0.475^{* * *} \\
(0.088)\end{array}$ & $\begin{array}{c}0.221^{* *} \\
(0.104)\end{array}$ & $\begin{array}{c}0.253^{* *} \\
(0.116)\end{array}$ \\
\hline Scholarship (residual) & $\begin{array}{c}-0.283^{* * * *} \\
(0.079)\end{array}$ & $\begin{array}{c}-0.277^{* * *} \\
(0.079)\end{array}$ & $\begin{array}{c}-0.298^{* * *} \\
(0.075)\end{array}$ & $\begin{array}{c}-0.296^{* * *} \\
(0.076)\end{array}$ \\
\hline z-management (residual) & $\begin{array}{c}0.091^{* * *} \\
(0.029)\end{array}$ & & & \\
\hline z-operations (residual) & & $\begin{array}{c}0.070^{* * *} \\
(0.026)\end{array}$ & & $\begin{array}{c}0.023 \\
(0.034)\end{array}$ \\
\hline z-people (residual) & & & $\begin{array}{c}0.167^{* * * *} \\
(0.041) \\
\end{array}$ & $\begin{array}{c}0.142^{* * * *} \\
(0.052)\end{array}$ \\
\hline Observations & 35964 & $\begin{array}{c}35964 \\
200\end{array}$ & 35964 & $\begin{array}{c}35964 \\
200\end{array}$ \\
\hline \# schools & 299 & 299 & 299 & 299 \\
\hline
\end{tabular}

Notes: Standard errors are clustered by school. The dependent variable student value added is estimated by using the residuals of a regression of the endline test score on the baseline test score for each student. All specifications include yeArpą fubject dummies. The management scores are: $\mathrm{z}$-management is the standardized average of the z-scores of each individual management practice. zoperations and z-people are the standardized average of the z-scores of each individual management practice relating to operations and people, respectively. All management scores are residualized on the full set of controls. Controls include those listed in Table 2. 
Table A4: School management practices and student value added in each type of school (lagged test score specification)

\begin{tabular}{|c|c|c|c|c|c|c|c|c|}
\hline \multirow{2}{*}{$\begin{array}{l}\text { Panel A: } \\
\text { No controls }\end{array}$} & \multicolumn{4}{|c|}{ Public schools } & \multicolumn{4}{|c|}{ Private schools } \\
\hline & $\begin{array}{c}(1) \\
\text { endline } \\
\text { score }\end{array}$ & $\begin{array}{c}(2) \\
\text { endline } \\
\text { score }\end{array}$ & $\begin{array}{c}(3) \\
\text { endline } \\
\text { score }\end{array}$ & $\begin{array}{c}(4) \\
\text { endline } \\
\text { score }\end{array}$ & $\begin{array}{c}(5) \\
\text { endline } \\
\text { score }\end{array}$ & $\begin{array}{c}(6) \\
\text { endline } \\
\text { score }\end{array}$ & $\begin{array}{c}(7) \\
\text { endline } \\
\text { score }\end{array}$ & $\begin{array}{c}(8) \\
\text { endline } \\
\text { score }\end{array}$ \\
\hline z-management & $\begin{array}{c}0.183^{* * *} \\
(0.037)\end{array}$ & & & & $\begin{array}{c}0.041 \\
(0.028)\end{array}$ & & & \\
\hline z-operations & & $\begin{array}{c}0.143^{* * *} \\
(0.032)\end{array}$ & & $\begin{array}{c}0.078^{*} \\
(0.041)\end{array}$ & & $\begin{array}{c}0.028 \\
(0.026)\end{array}$ & & $\begin{array}{c}-0.018 \\
(0.035)\end{array}$ \\
\hline z-people & & & $\begin{array}{c}0.381^{* * *} \\
(0.069)\end{array}$ & $\begin{array}{c}0.264^{* * *} \\
(0.090)\end{array}$ & & & $\begin{array}{c}0.099^{* *} \\
(0.041)\end{array}$ & $\begin{array}{c}0.119^{* *} \\
(0.056)\end{array}$ \\
\hline Lagged test score & $\begin{array}{c}0.451^{* * *} \\
(0.040)\end{array}$ & $\begin{array}{c}0.451^{* * *} \\
(0.040)\end{array}$ & $\begin{array}{c}0.463^{* * * *} \\
(0.041)\end{array}$ & $\begin{array}{c}0.455^{* * *} \\
(0.041)\end{array}$ & $\begin{array}{c}0.306^{* * *} \\
(0.019)\end{array}$ & $\begin{array}{c}0.307^{* * *} \\
(0.019)\end{array}$ & $\begin{array}{c}0.304^{* * *} \\
(0.019)\end{array}$ & $\begin{array}{c}0.304^{* * *} \\
(0.019)\end{array}$ \\
\hline Observations & 7157 & 7157 & 7157 & 7157 & 28807 & 28807 & 28807 & 28807 \\
\hline \# schools & 109 & 109 & 109 & 109 & 190 & 190 & 190 & 190 \\
\hline Panel B: & \multicolumn{4}{|c|}{ Public schools } & \multicolumn{4}{|c|}{ Private schools } \\
\hline With controls & $\begin{array}{c}(1) \\
\text { endline } \\
\text { score }\end{array}$ & $\begin{array}{c}(2) \\
\text { endline } \\
\text { score }\end{array}$ & $\begin{array}{c}(3) \\
\text { endline } \\
\text { score }\end{array}$ & $\begin{array}{c}(4) \\
\text { endline } \\
\text { score }\end{array}$ & $\begin{array}{c}(5) \\
\text { endline } \\
\text { score }\end{array}$ & $\begin{array}{c}\text { (6) } \\
\text { endline } \\
\text { score }\end{array}$ & $\begin{array}{c}(7) \\
\text { endline } \\
\text { score }\end{array}$ & $\begin{array}{c}(8) \\
\text { endline } \\
\text { score }\end{array}$ \\
\hline z-management & $\begin{array}{c}0.170^{* * *} \\
(0.045)\end{array}$ & & & & $\begin{array}{c}0.042 \\
(0.028)\end{array}$ & & & \\
\hline z-operations & & $\begin{array}{c}0.132^{* * *} \\
(0.037)\end{array}$ & & $\begin{array}{c}0.083^{* *} \\
(0.040)\end{array}$ & & $\begin{array}{c}0.022 \\
(0.025)\end{array}$ & & $\begin{array}{l}-0.029 \\
(0.033)\end{array}$ \\
\hline z-people & & & $\begin{array}{c}0.336^{* * *} \\
(0.087)\end{array}$ & $\begin{array}{c}0.223^{* *} \\
(0.097)\end{array}$ & & & $\begin{array}{c}0.124^{* * *} \\
(0.041)\end{array}$ & $\begin{array}{c}0.153^{* * *} \\
(0.055)\end{array}$ \\
\hline Lagged test score & $\begin{array}{c}0.444^{* * * *} \\
(0.040) \\
\end{array}$ & $\begin{array}{c}0.443^{* * *} \\
(0.040) \\
\end{array}$ & $\begin{array}{c}0.456^{* * * *} \\
(0.040) \\
\end{array}$ & $\begin{array}{c}0.448^{* * * *} \\
(0.040) \\
\end{array}$ & $\begin{array}{c}0.293^{* * *} \\
(0.018) \\
\end{array}$ & $\begin{array}{c}0.295^{* * *} \\
(0.018) \\
\end{array}$ & $\begin{array}{c}0.290^{* * * *} \\
(0.018) \\
\end{array}$ & $\begin{array}{c}0.290 * * * \\
(0.018) \\
\end{array}$ \\
\hline Observations & 7157 & 7157 & 7157 & 7157 & 28807 & 28807 & 28807 & 28807 \\
\hline \# schools & 109 & 109 & 109 & 109 & 190 & 190 & 190 & 190 \\
\hline
\end{tabular}

Notes: Standard errors are clustered by school. The dependent variable, student value added, is estimated by using the residuals of a regression of the end-line test score on the baseline test score for each student. z-management is the standardized overall management index. z-operations and z-people are the standardized average scores of the operations questions and people management questions. Controls include those listed in Table 2: student controls (indicators for female student, scheduled caste, parents are literate, parents are manual laborers, and a household assets index), teacher controls (share of teachers with a degree, share with teacher training, average teaching experience, average number of work days, head teacher teaching experience and head teacher education) and school controls (log of number of students, average share of female students, of students from scheduled castes, of literate parents and of laborer parents). Includes subject and year fixed effects. 
Table A5: School management practices and student value added — pooled across public and private schools (lagged test score specification)

\begin{tabular}{|c|c|c|c|c|c|}
\hline \multirow[t]{2}{*}{ Panel A: No controls } & \multicolumn{5}{|c|}{ Public and private schools } \\
\hline & $\begin{array}{c}(1) \\
\text { endline } \\
\text { score }\end{array}$ & $\begin{array}{c}\text { (2) } \\
\text { endline } \\
\text { score }\end{array}$ & $\begin{array}{c}(3) \\
\text { endline } \\
\text { score }\end{array}$ & $\begin{array}{c}(4) \\
\text { endline } \\
\text { score }\end{array}$ & $\begin{array}{c}(5) \\
\text { endline } \\
\text { score }\end{array}$ \\
\hline Private $=1$ & $\begin{array}{c}0.353^{* * *} \\
(0.059)\end{array}$ & $\begin{array}{c}0.255^{* * *} \\
(0.060)\end{array}$ & $\begin{array}{c}0.317^{* * *} \\
(0.056)\end{array}$ & $\begin{array}{c}0.061 \\
(0.084)\end{array}$ & $\begin{array}{c}0.105 \\
(0.099)\end{array}$ \\
\hline Scholarship $=1$ & $\begin{array}{c}-0.245^{* * *} \\
(0.079)\end{array}$ & $\begin{array}{c}-0.259^{* * *} \\
(0.080)\end{array}$ & $\begin{array}{c}-0.253^{* * *} \\
(0.082)\end{array}$ & $\begin{array}{c}-0.278^{* * *} \\
(0.075)\end{array}$ & $\begin{array}{c}-0.274^{* * *} \\
(0.076)\end{array}$ \\
\hline z-management & & $\begin{array}{c}0.090^{* * *} \\
(0.025)\end{array}$ & & & \\
\hline z-operations & & & $\begin{array}{c}0.071^{* * *} \\
(0.022)\end{array}$ & & $\begin{array}{c}0.026 \\
(0.030)\end{array}$ \\
\hline z-people & & & & $\begin{array}{c}0.162^{* * *} \\
(0.037)\end{array}$ & $\begin{array}{c}0.131^{* * *} \\
(0.050)\end{array}$ \\
\hline Lagged test score & $\begin{array}{c}0.315^{* * * *} \\
(0.018)\end{array}$ & $\begin{array}{c}0.309^{* * * *} \\
(0.018)\end{array}$ & $\begin{array}{c}0.310 * * * \\
(0.018)\end{array}$ & $\begin{array}{c}0.307^{* * * *} \\
(0.018)\end{array}$ & $\begin{array}{c}0.307^{* * * *} \\
(0.018)\end{array}$ \\
\hline Observations & 35964 & 35964 & 35964 & 35964 & 35964 \\
\hline \# schools & 299 & 299 & 299 & 299 & 299 \\
\hline \multirow[t]{2}{*}{ Panel B: with controls } & \multicolumn{5}{|c|}{ Public and private schools } \\
\hline & $\begin{array}{c}(1) \\
\text { endline } \\
\text { score }\end{array}$ & $\begin{array}{c}\text { (2) } \\
\text { endline } \\
\text { score }\end{array}$ & $\begin{array}{c}(3) \\
\text { endline } \\
\text { score }\end{array}$ & $\begin{array}{c}(4) \\
\text { endline } \\
\text { score }\end{array}$ & $\begin{array}{c}(5) \\
\text { endline } \\
\text { score }\end{array}$ \\
\hline Private $=1$ & $\begin{array}{c}0.501^{* * *} \\
(0.087)\end{array}$ & $\begin{array}{c}0.406^{* * *} \\
(0.087)\end{array}$ & $\begin{array}{c}0.467^{* * *} \\
(0.085)\end{array}$ & $\begin{array}{c}0.211^{* *} \\
(0.099)\end{array}$ & $\begin{array}{c}0.241^{* *} \\
(0.108)\end{array}$ \\
\hline Scholarship = 1 & $\begin{array}{c}-0.258^{* * *} \\
(0.078)\end{array}$ & $\begin{array}{c}-0.278^{* * *} \\
(0.077)\end{array}$ & $\begin{array}{c}-0.271^{* * *} \\
(0.078)\end{array}$ & $\begin{array}{c}-0.295^{* * *} \\
(0.073)\end{array}$ & $\begin{array}{c}-0.294^{* * *} \\
(0.074)\end{array}$ \\
\hline z-management & & $\begin{array}{c}0.092^{* * *} \\
(0.026)\end{array}$ & & & \\
\hline z-operations & & & $\begin{array}{c}0.070^{* * *} \\
(0.023)\end{array}$ & & $\begin{array}{c}0.022 \\
(0.028)\end{array}$ \\
\hline z-people & & & & $\begin{array}{c}0.170^{* * *} \\
(0.036)\end{array}$ & $\begin{array}{c}0.146^{* * *} \\
(0.046)\end{array}$ \\
\hline Lagged test score & $\begin{array}{c}0.304^{* * * *} \\
(0.018)\end{array}$ & $\begin{array}{c}0.298 * * * \\
(0.018) \\
\end{array}$ & $\begin{array}{c}0.300^{* * * *} \\
(0.018)\end{array}$ & $\begin{array}{c}0.296^{* * *} \\
(0.017)\end{array}$ & $\begin{array}{c}0.296^{* * *} \\
(0.017)\end{array}$ \\
\hline Observations & 35964 & 35964 & 35964 & 35964 & 35964 \\
\hline \# schools & 299 & 299 & 299 & 299 & 299 \\
\hline
\end{tabular}

Notes: Standard errors are clustered by school. The dependent variable student value added is estimated by using the residuals of a regression of the end-line test score on the baseline test score for each student. z-management is the standardized overall management index. z-operations and z-people are the standardized average scores of the operations questions and people management questions. Private refers to an indicator for private school, and scholarship is an indicator for whether the student received a scholarship in the Muralidharan and Sundararaman (2015) school choice experiment. Controls include those listed in Table 2: student controls (indicators for female student, scheduled caste, parents are literate, parents are manual laborers, and a household assets index), teacher controls (share of teachers with a degree, share with teacher trajning, gverage teaching experience, average number of work days, head teacher teaching experience and head teacher education) and school controls (log of number of students, average share of female students, of students from scheduled castes, of literate parents and of laborer parents). Includes subject and year fixed effects. 
Table A6: School management practices and teacher flows: alternative outcomes

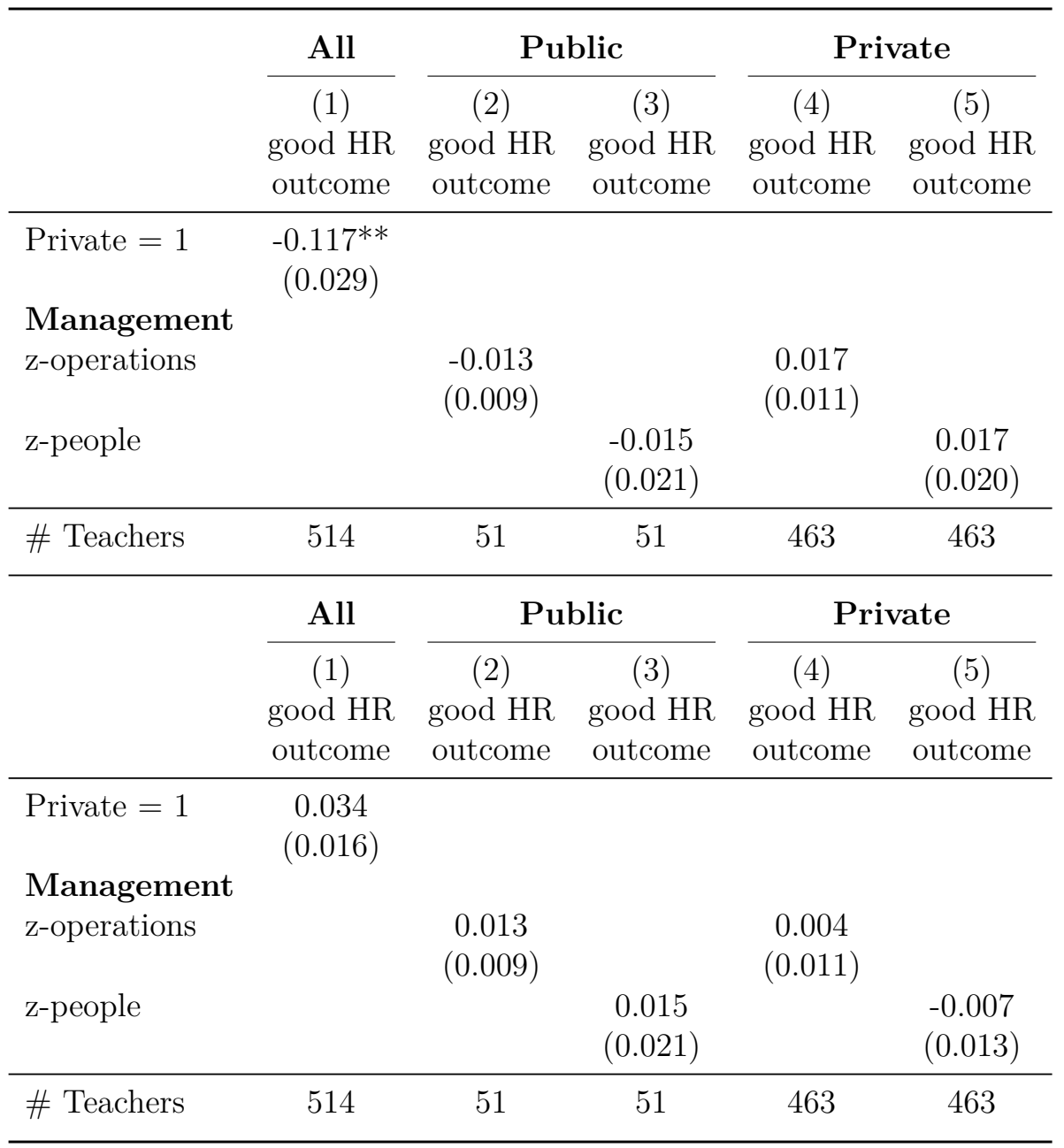

Notes: The Good HR outcome alternative measure 1 is defined in the same way as the original variable, but a high value added teacher is defined as the top 2 within schools that have 5 or more teachers. A low value added teacher is the defined as either of the bottom 2 within schools that have 5 or more teachers. The Good HR outcome alternative measure 2 defines high value added teachers as those above the median teacher value added within the school, and low value added teachers are defined as below the median. Standard errors are clustered by school. The sample uses only schools which had data about teacher transfers during year 2 of the Muralidharan and Sundararaman (2015) experiment (2009). The dependent variable, "good HR outcome", is a binary outcome. It takes a value of 1 if a high value added teacher was transferred in or retained in the school, or if a low value added teacher is transferred out of the school. It takes a value of 0 otherwise. Teacher value added is estimated using the Chetty et al. (2014) method and vam Stata command. A teacher is coded as "high value added" when their year 1 value added is the highest within their school. A teacher is coded as "low value added" when their year 1 value added is the lowest within their school. Private refers to an indicator for private school. z-operations and z-people are the standardized average scores of the operations questions and people management questions. Controls include school controls listed in Table 2: log of number of students, average share of female students, of students from scheduled castes, of literate parents and of laborer parents.

App. 9 


\section{B Data Appendix}

\section{B.1 World Management Survey sampling weights}

The World Management Survey average scores used in this paper include survey weights. These are calculated as the inverse probability of being interviewed on log of number of students, public status, and population density by state, province, or NUTS 2 region as a measure of location). Samples include both public and private schools, with the exception of Colombia where data is only available to public primary schools.

\section{B.2 The Development World Management Survey methodology}

In original WMS, the survey is administered by highly trained interviewers who ask a series of scripted and unscripted questions until they gather all the information they need to score the practices. The interviewers are generally graduate students in business and economics programs from highly ranked institutions, and undergo a week-long intensive WMS training program. This program teaches them how to ask the WMS questions in open-ended format, and how to arrive at a score that combines the various facets of a manager's answer into one score. In the D-WMS, however, we remove a large portion of the discretion interviewers have by separating the three types of questions and requiring separate scores for each sub-question. This reduces measurement error as the interviewers have an almost-checkbox style grid, and is more appropriate for settings where very high quality interviewers are not available or not feasible due to budget constraints. Below we include all the original WMS topics and the three factors (implementation, usage, monitoring) along with the example questions asked by the interviewers.

\section{B.2.1 Scoring example and interpretation}

We use an example to illustrate the type of information included in the interviews and codified in the survey, and how the expansions aid in identifying bottlenecks. On the topic of data-driven student transition to higher grades, principals are asked open-ended questions such as "What type of information about the individual students is available to teachers at the beginning of the academic year?" and "What do you think are the main points of transition/promotion for students and how is this communicated to your teachers?". Higher scores are awarded to principals who can discuss an array of data relevant in their school and context, and ensure the information is collected regularly, communicated to teachers well, and used to inform student transitions.

For the first factor, implementation, a school would receive a score of 1 if there is no data available. A score of 1.5 means that the school has some limited information for students, and while it may be of lower quality relative to official examinations, still constitutes a better practice than having nothing at all. A score of a 2 means there is some data is available, such as end-of-year examinations and teacher impressions. A score of a 3 means the schools uses a range of data, including results for quarterly, mid-year and end of-the year examinations plus health information, teacher impressions and baseline tests. The score of 2.5 would sit 
somewhere in the middle, if the school has a range of academic and behaviour data (an improvement on simply collecting end-of-year examinations or teacher impressions) but not quite a large enough range collected over multiple instances with different instruments.

For the second factor, usage, a score of 1 means that the principal does not understand basic transition points for students (such as progress between units). A score of 1.5 recognizes that the principal has a personal understanding of these points but does not communicate with teachers about these points. A score of 2 means that the principal internalizes the important transition points but also communicates with teachers to build shared understanding, though very informally and infrequently. A score of 2.5 means that this communication is more regular, albeit still informal. For a score of 3 or above, the understanding of critical transitions needs to be formally acknowledged and understood by the principal as well as the main teaching staff.

For the third factor, monitoring, a score of 1 would imply teachers have no knowledge of prior achievement, and thus cannot consider this data in critical transitions. A score of 1.5 means teachers are at least given progress cards, but no real action is taken. A score of 2 means teachers are made aware of past performance and there is an expectation that issues should be addressed, but the approach is unstructured. A score of 2.5 is awarded when there is an informal communication structure in place to link prior teachers and inform critical transition moments. For a score of 3 or above, the school needs to have a process to formally verify student outcomes at critical stages, regularly, and have a structured way to address weaknesses.

Overall, a score of a 3 or below for this topic means performance data is not be recorded systematically with a range of tools that would allow for a more thorough understanding of a studentâs strengths and weaknesses. Further it is not integrated or easy to use or shared with a range of stakeholders. The importance of the D-WMS for measurement in our context stems from nearly all public schools having scores below 3 . 


\section{Table B1: Survey questions: Operations management questions}

\section{Process implementation}

Process usage Questions

Questions

How do you ensure that all students of a given grade are learning the same topics in the same way within a similar timeframe?

\begin{tabular}{lr}
\hline 2. & Personalization \\
of & Instruction \\
and Learning
\end{tabular}

How much does the school try to identify individual student needs and accommodate these needs within in the classroom?
What type of information about the individual students is available to teachers at the beginning of the academic year?

4. Adopting Educational Best Practices

How do you encourage the teachers to incorporate new teaching practices into the classroom?

5. Continuous Im- When you have a problem in provement the school, how do you come to know about them and what are the steps you go through to fix them?

6. Performance What kind of main parameters Tracking do you use to track school performance and what documents are you using to inform this tracking?

7. Performance Re- How often do you have meetview ings to review the parameters? $\begin{array}{ll}\begin{array}{l}\text { 8. Performance Dia- } \\ \text { logue }\end{array} & \text { Can you tell me about a recent } \\ \text { review meeting you have had? }\end{array}$

9. Consequence Man- After a review meeting, how agement

Are people aware of their responsibilities and actions that must be taken?

10. Balance of Tar- What goals do you have set for gets/Goal Metrics your school?
Why did you and the teachers decide on the current curriculum, textbooks and other materials and lesson plans used throughout the year?

How do you make sure students and parents are engaged in the students' learning?

What do you think are the main points of transition/promotion for students and how is this communicated to your teachers?

How do you make sure the teachers are using the new techniques you are trying to introduce?

Who is involved in improving/suggesting improvements to the process so these issues do not happen again?

How often are these main parameters measured?

Who is involved in these meetings and who gets to see the results of these meetings?

What kind of data or information about the parameters do you normally have with you?

How would you make sure this problem does not happen again?

Can you tell me about any specific goals for departments, teachers and staff?

Process monitoring

How do you keep track of what teachers are doing in the classrooms?

How do you keep track of what teachers are doing in the classrooms to ensure that different student needs are taken care of?

Does the school use any data to consider student promotions through critical transitions (such as grade promotions or unit progressions)?

By what means and how often are these learnings shared across teachers and subjects and how often?

Who is involved in resolving these issues, that is, in deciding what course of action will be taken to resolve the issue?

If I were to walk through your school, how could I tell how it is doing compared to its main parameters?

After reviewing these parameters, what is the action plan, that is what steps do people take after leaving the meeting? What type of feedback do you get during these meetings and how do you get to solving the problems raised?

How long does it typically go between when a problem starts and you realize this and start solving it?

How are your school goals linked to student outcomes and to the goals of the school board system (government/ICSE/CBSE)?

\begin{tabular}{|c|c|c|}
\hline $\begin{array}{l}\text { 11. Interconnection } \\
\text { of Targets/Goals }\end{array}$ & $\begin{array}{l}\text { How do you learn of the goals } \begin{array}{l}\text { If I were a teacher or another } \\
\text { the school system expects of member of the school, what } \\
\text { you? }\end{array} \\
\text { kind of goals would I have? }\end{array}$ & $\begin{array}{l}\text { How do you communicate to } \\
\text { your teachers and staff what } \\
\text { their goals are? }\end{array}$ \\
\hline $\begin{array}{l}\text { 12. Time Horizon of } \\
\text { Targets/Goals }\end{array}$ & $\begin{array}{ll}\text { Which goals would you say get } & \text { What kind of time-scale are } \\
\text { the most emphasis? } & \text { you looking at with your goals? }\end{array}$ & $\begin{array}{l}\text { Could you meet all your short } \\
\text { term goals but miss your long- } \\
\text { run goals? }\end{array}$ \\
\hline $\begin{array}{l}\text { 13. Stretch of Tar- } \\
\text { gets/Goals }\end{array}$ & $\begin{array}{l}\text { How are your goals bench- } \begin{array}{l}\text { Do you feel that all the depart- } \\
\text { marked? }\end{array} \\
\text { ments/areas have goals that } \\
\text { are just as hard or would some } \\
\text { App.anes /departments get easier } \\
\text { targets? }\end{array}$ & $\begin{array}{l}\text { On average, how often would } \\
\text { you say that the school meets } \\
\text { their goals? }\end{array}$ \\
\hline $\begin{array}{l}\text { 14. Clarity } \\
\text { parability }\end{array}$ & $\begin{array}{l}\text { If I asked one of the teach- } \\
\text { ers directly about their indi- } \\
\text { vidual goals, what would they } \\
\text { toll mo? }\end{array}$ & $\begin{array}{l}\text { How do people know about } \\
\text { their own performance when } \\
\text { compared to other people's }\end{array}$ \\
\hline
\end{tabular}




\section{Table B2: Survey questions: People management questions}

\section{Process implementation}

formulating, adopting and putting into effect management practices

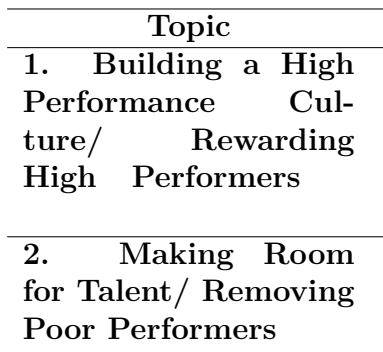

What criteria do you use and how often do you identify your worst teachers?
Process usage

carrying out and using management practices frequently and efficiently

Questions

What types of monetary or non-monetary rewards are given to teachers and how are these linked to the ranking teachers get?

If you had a teacher who is struggling or who could not do their job properly, what would you do? What if you had a teacher who would not do their job, as in slacking off, what would you do then?

\begin{tabular}{ll}
\hline 3. Promoting High & $\begin{array}{l}\text { What criteria do you use and } \\
\text { Performers }\end{array}$ \\
& best teachers?
\end{tabular}
What types of career and teacher development opportunities are provided?

\section{Process monitoring}

monitoring the appropriateness and efficient use of management practices

\author{
By what means and how often \\ do you evaluate and rate your \\ teachers? \\ How long does it take to ad- \\ dress the issue once you come \\ to know that a teacher is per- \\ forming badly?
}

How do you make decisions about promotion/progression of teachers and additional opportunities within the school, such as performance, years of service, etc.?

\begin{tabular}{|c|c|c|c|}
\hline 4. Managing Talent & $\begin{array}{l}\text { Who decides how many and } \\
\text { which teachers (full-time regu- } \\
\text { lar members of staff) to hire? }\end{array}$ & $\begin{array}{l}\text { Where do you seek out and } \\
\text { find teachers and how do you } \\
\text { ensure you have the teachers } \\
\text { you need for the subjects you } \\
\text { have? }\end{array}$ & $\begin{array}{l}\text { How do you decide which } \\
\text { teachers should be hired? }\end{array}$ \\
\hline 5. Retaining talent & $\begin{array}{l}\text { When one of your best teachers } \\
\text { wants to leave the school, what } \\
\text { do you do? }\end{array}$ & $\begin{array}{l}\text { Could you give me an example } \\
\text { of what you would be able to } \\
\text { offer to try and keep that best } \\
\text { teacher in your school? }\end{array}$ & $\begin{array}{l}\text { How would you know if your } \\
\text { best teachers are happy work- } \\
\text { ing in this school? }\end{array}$ \\
\hline $\begin{array}{l}6 . \quad \text { Creating a } \\
\text { Distinctive Employee } \\
\text { Value Proposition }\end{array}$ & $\begin{array}{l}\text { What are the professional ben- } \\
\text { efits of working at your school? }\end{array}$ & $\begin{array}{l}\text { How do teachers come to know } \\
\text { that working at your school is } \\
\text { better than others? }\end{array}$ & $\begin{array}{l}\text { How do you check to see if } \\
\text { teachers are aware of the bene- } \\
\text { fits of working at your school? }\end{array}$ \\
\hline
\end{tabular}

App. 13 
Figure B1: Sample report card from an AP school

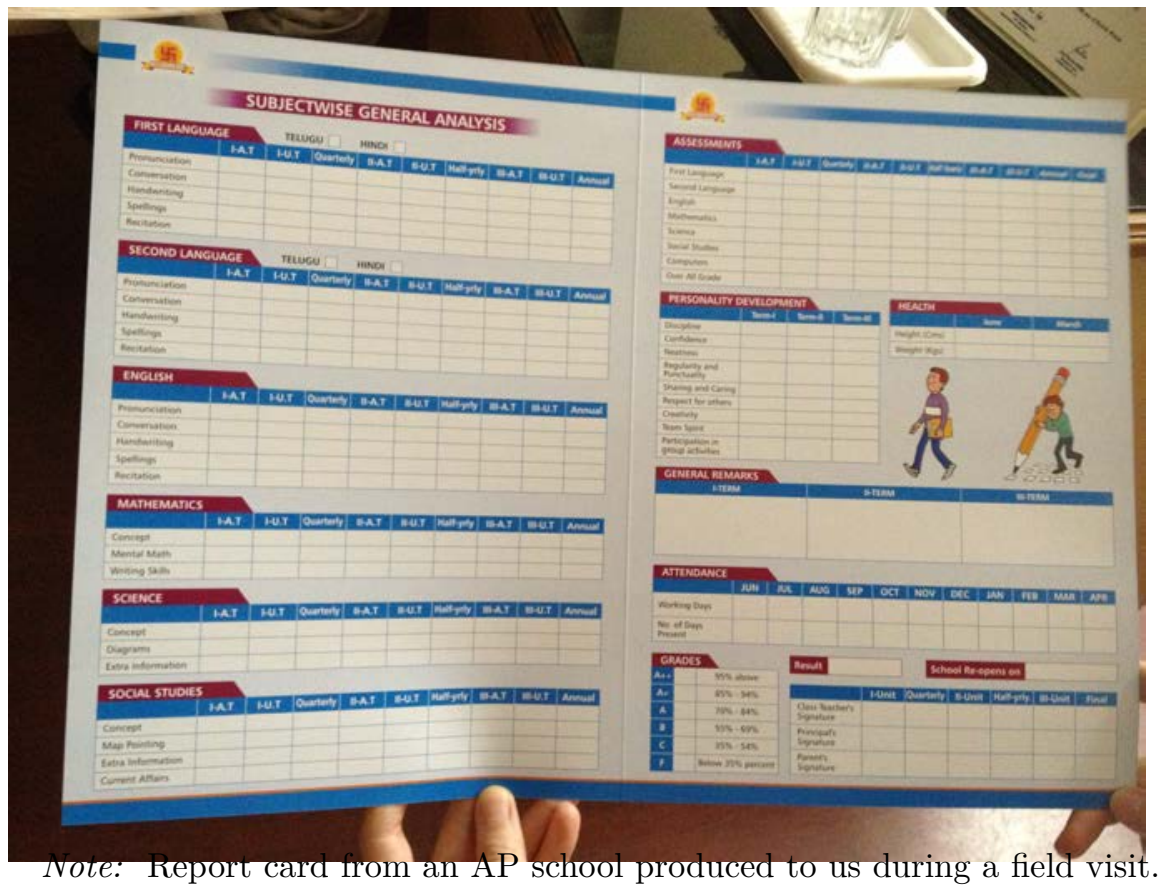

App. 14 


\section{B.3 Teacher Value Added}

For the sake of clarity, we reproduce here the essence of the statistical model underlying the teacher value added model from Chetty et al. (2014) in Equation 8, below. It shows how the authors suggest estimating teacher value added to extract the teacher effect, $\mu_{j t}$ from a panel of student-level data. $A_{i(t)}$ and $A_{i(t-1)}$ are the standardized end-of-year test score for student $i$ in years $t$ and $t-1$. Controlling for students' prior year test scores (or, lagged test scores) captures "most of the sorting of students to teachers that is relevant for future test achievement." ${ }^{30}$ Further, there is some consensus in the literature that including a student's prior test scores is the best proxy available for the cumulative learning and other characteristics (such as parent's input and individual motivation) up to the point where the "new" teacher is matched with the student. ${ }^{31}$ Our data includes subject-specific test scores administered by the APSC project team for English, Telugu, Science and social studies and Hindi. As only Math and Telugu tests are administered in all the primary school grades (1 through 5 in Andhra Pradesh), we focus on these two subjects. The vector $X_{i t}$ includes student and classroom characteristics as controls, namely gender, caste, religion, whether parents are labourers and whether parents are literate. Each student can be matched to a teacher, year, class and subject. The equation is as follows:

$$
\begin{aligned}
A_{i(t)}=\alpha A_{i(t-1)}+ & \beta X_{i t}+\quad \nu_{i t} \\
& \text { where } \quad \nu_{i t}=\mu_{j t}+\theta_{c}+\varepsilon_{i t}
\end{aligned}
$$

and the residual term $\nu_{i j t}$ is expressed by Chetty et al. (2014) as a composite of teacher value added $\left(\mu_{j t}\right)$, exogenous class shocks $\left(\theta_{c}\right)$ and idiosyncratic student-level variation $\left(\varepsilon_{i t}\right) .{ }^{32}$ The individual "teacher effect" is not assumed to be fixed over time but rather is allowed to fluctuate stochastically over time. They do not place restrictions on the stochastic process except that they must follow a stationary process. ${ }^{33}$

In short, Chetty et al. (2014) predict each teacher's value added in a school year based on the mean test scores of students she taught in other (prior and later) years. However, their innovation is that they allow teacher quality to vary over years by essentially regressing student scores in year $t$ on the average scores in other years, "allowing the coefficients to vary across different lags." They then estimate the autocovariance of scores across classrooms

\footnotetext{
${ }^{30}$ Chetty et al. (2014)

${ }^{31}$ For example, Guarino et al. (2014)

${ }^{32}$ Chetty et al. (2014) note that their approach is similar to Kane and Staiger (2008), except that it accounts for drift. In Kane and Staiger (2008), the authors use "the student residuals $\nu$ to form empirical Bayes estimates of each teacher's value added." Essentially, this approach uses the noisy estimate of teacher value added multiplied by an estimate of its reliability, that is, the mean residual multiplied by ratio of (signal)-variance to (signal + noise)-variance. In a simulation exercise, however, Guarino et al. (2014) found that empirical Bayes estimates were not the most reliable estimators among the six most common studied. Another common approach is to treat two of the components of $\nu_{i t}$, namely the teacher and classroom effects as fixed effects, for example, as in Gordon et al. (2006), Rockoff (2004).

${ }^{33}$ As Chetty et al. (2014) explain, it thus requires an assumption that mean teacher quality does not vary across calendar years and that the correlation of teacher quality, class shocks and student shocks across pairs of years depends only on the time elapsed between the years. Formally: $\mathbb{E}\left[\mu_{j t} \mid t\right]=\mathbb{E}[\varepsilon i t]=0$, $\operatorname{Cov}\left(\mu_{j t}, \mu_{j(t+s)}\right)=\sigma_{\mu s}, \operatorname{Cov}\left(\varepsilon_{i t}, \varepsilon_{i(t+s)}\right)=\sigma_{\varepsilon s} \forall t$.
} 
taught by each teacher non-parametrically and use that information to account for "drift" in teacher quality.

They construct the estimator in three steps: The first is to run the regression in Equation 8 to recover the residuals, $\nu_{i j t}$. They use variation across students taught by the same teacher, which is a departure from previous techniques that used both within-teacher and between-teacher variation. The second step is to estimate mean test score residuals in classrooms in year $t$ based on mean test score residuals in prior years. If we let the mean residual test score in the class teacher $j$ teaches in year $t$ be $\bar{A}_{j t}=\frac{1}{n} \sum_{i \in\{i: j(i, t)=j\}} \nu_{i t}$, and $\mathbf{A}_{j}^{-t}=\left(\bar{A}_{j 1}, \ldots, \bar{a}_{j(t-1)}\right)^{\prime}$ is the vector of mean residual scores prior to year $t$ in classes taught by teacher $j$, then a regression of $\bar{A}_{j t}$ on $\mathbf{A}_{j}^{-t}$ results in a set of coefficients that are the best linear predictors of $\bar{A}_{j t}$ based on prior scores. ${ }^{34}$ The third step is using the coefficients recovered from the "best linear predictor" to predict the teachers' value added for year $t$, using a leave-year-out approach.

Their results using US data suggest that a 1 standard deviation improvement in teacher quality leads to higher test scores of approximately 0.14 SD for maths and 0.1 SD in English. In their measure, they scale teacher value added such that "the average teacher has value added $\mu_{j t}=0$ and the effect of a 1 unit increase in teacher value added on end-of-year test scores is $1 . " 35$ It is this methodology that we use to calculate teacher value added in the context of the data available for this paper. ${ }^{36}$

\section{B.4 Teacher classroom practices}

We use a set of fourteen indicators related to classroom practices in self-reported teacher questionnaires administered to all teachers by enumerators, along with two indicators in audit data from classroom observation visits. These were collected independent of the student tests and the D-WMS management survey.

Survey questions: The fourteen self-reported indicators include information on classroom preparedness (teacher makes lesson plans, has textbook and/or workbook, checks hygiene daily), time spent teaching (the $\%$ time teaching, $\%$ time on teaching activities, $\%$ time "on task"), and time spend on remedial activities (time spent on remedial activities as well as above average time spent remedial attention in class, outside class, helping arrange private tuition, helping at home, and other type of help). The two audit indicators include whether the teacher was present in the school and whether they were actively teaching in class. We describe each teacher practice and how it is coded below.

Index construction: We aggregated all sixteen items into a single index using the Anderson (2008) method. This methodology weights the impact of the included variables by the

\footnotetext{
${ }^{34}$ We mention the OLS equivalent here for ease of exposition, but the technique used by Chetty et al. (2014) is analogous to the OLS regression method and describe it in detail in their paper.

${ }^{35}$ Chetty et al. (2014)

${ }^{36}$ To implement their method we used the accompanying Stata command vam.
} 
Table B3: Teacher practices index

Variable

Question

Coding

\begin{tabular}{|c|c|c|}
\hline Has lesson plan & $\begin{array}{l}\text { Do you prepare a lesson plan (teaching plan) before teaching? (1) } \\
\text { Yes, (2) No }\end{array}$ & $=1$ if $(1)$ \\
\hline $\begin{array}{l}\text { Has } \\
\text { book/workbook }\end{array}$ & $\begin{array}{l}\text { Do you have a copy of the textbook for each class you teach? Do } \\
\text { you have a copy of the workbook for each class you teach? For each } \\
\text { question: (1) All, (2) Some, (3) None }\end{array}$ & $\begin{array}{l}=1 \text { if }(1) \text { in both ques- } \\
\text { tions }\end{array}$ \\
\hline Checks daily hygiene & $\begin{array}{l}\text { How often are the children observed for health/hygiene related } \\
\text { habits, like cleanliness of nails, teeth and washing hands before } \\
\text { meals, of the children by you? (1) Daily, (2) Few times a week, (3) } \\
\text { Few times a month, (4) Few times a year, (5) Never }\end{array}$ & $=1$ if $(1)$ \\
\hline $\begin{array}{l}\text { Share time teaching ac- } \\
\text { tivities }\end{array}$ & $\begin{array}{l}\text { How much time do you spend in a typical day on each of the follow- } \\
\text { ing activities? (A) Teaching Activity, (B) Preparing for Classes, (C) } \\
\text { Correcting Homework, (D) Maintaining Order and Discipline, (E) } \\
\text { Administrative/Paper work, (F) Breaks during School, (G) Getting } \\
\text { children to attend school, (H) Mid-day meals, (I) Extra Classes, (J) } \\
\text { Others }\end{array}$ & $\begin{array}{l}\text { share of total time } \\
\text { spent in }(A),(B),(C), \\
\text { and }(I) \text {. }\end{array}$ \\
\hline Share time on task & $\begin{array}{l}\text { How much time do you spend in a typical day on each of the follow- } \\
\text { ing activities? (A) Teaching Activity, (B) Preparing for Classes, (C) } \\
\text { Correcting Homework, (D) Maintaining Order and Discipline, (E) } \\
\text { Administrative/Paper work, (F) Breaks during School, (G) Getting } \\
\text { children to attend school, (H) Mid-day meals, (I) Extra Classes, (J) } \\
\text { Others }\end{array}$ & $\begin{array}{l}\text { share of total time } \\
\text { spent in }(B),(C),(I)\end{array}$ \\
\hline $\begin{array}{l}\text { Share time teaching } \\
\text { only }\end{array}$ & $\begin{array}{l}\text { How much time do you spend in a typical day on each of the follow- } \\
\text { ing activities? (A) Teaching Activity, (B) Preparing for Classes, (C) } \\
\text { Correcting Homework, (D) Maintaining Order and Discipline, (E) } \\
\text { Administrative/Paper work, (F) Breaks during School, (G) Getting } \\
\text { children to attend school, (H) Mid-day meals, (I) Extra Classes, (J) } \\
\text { Others }\end{array}$ & $\begin{array}{l}\text { share of total time } \\
\text { spent in }(A) \text {. }\end{array}$ \\
\hline Remedial time attention & $\begin{array}{l}\text { Do you get time to provide remedial teaching to the students? (1) } \\
\text { Yes, (2) No }\end{array}$ & $=1$ if $(1)$ \\
\hline $\begin{array}{l}\text { Time spent in remedial } \\
\text { attention: }\end{array}$ & Do you get time to provide remedial teaching to the students? & \\
\hline $\begin{array}{l}\ldots \text { taking extra class } \\
\text { time }\end{array}$ & If yes, mention time in hours per week for this topic & $\begin{array}{l}=1 \text { if time spent is } \\
\text { above average of dis- } \\
\text { tribution }\end{array}$ \\
\hline $\begin{array}{l}\text {... paying extra atten- } \\
\text { tion in the class itself }\end{array}$ & If yes, mention time in hours per week for this topic & $\begin{array}{l}=1 \text { if time spent is } \\
\text { above average of dis- } \\
\text { tribution }\end{array}$ \\
\hline $\begin{array}{l}\text {... paying extra atten- } \\
\text { tion outside the class }\end{array}$ & If yes, mention time in hours per week for this topic & $\begin{array}{l}=1 \text { if time spent is } \\
\text { above average of dis- } \\
\text { tribution }\end{array}$ \\
\hline $\begin{array}{l}\text {... help children by ar- } \\
\text { ranging private tuition }\end{array}$ & If yes, mention time in hours per week for this topic & $\begin{array}{l}=1 \text { if time spent is } \\
\text { above average of dis- } \\
\text { tribution }\end{array}$ \\
\hline $\begin{array}{l}\text {... helping children in } \\
\text { studies at home }\end{array}$ & If yes, mention time in hours per week for this topic & $\begin{array}{l}=1 \text { if time spent is } \\
\text { above average of dis- } \\
\text { tribution }\end{array}$ \\
\hline ... others & If yes, mention time in hours per week for this topic & $\begin{array}{l}=1 \text { if time spent is } \\
\text { above average of dis- } \\
\text { tribution }\end{array}$ \\
\hline $\begin{array}{l}\text { Observed: } \\
\text { Teaching }\end{array}$ & $\begin{array}{l}\text { What is the teacher doing when you look for him/her? (A) Actively } \\
\text { Teaching or engaged with the children, (B) Passive teaching, (C) In } \\
\text { the class, but not teaching, (D) Out of class, and not teaching, (E) } \\
\text { Doing administrative/ paper work, (F) Talking to/accompanying } \\
\text { the MC, (G) Cannot find the teacher (absent) }\end{array}$ & $=1$ if $(\mathrm{A})$ \\
\hline $\begin{array}{l}\text { Observed: } \\
\text { Present }\end{array}$ & $\begin{array}{l}\text { What is the teacher doing when you look for him/her? (A) Actively } \\
\text { Teaching or engaged witA phpshlaren, (B) Passive teaching, (C) In } \\
\text { the class, but not teaching, (D) Out of class, and not teaching, (E) } \\
\text { Doing administrative/ paper work, (F) Talking to/accompanying } \\
\text { the MC, }(\mathrm{G}) \text { Cannot find the teacher (absent) } \\
=0 \text { if }(\mathrm{G}),=1 \text { otherwise }\end{array}$ & $=1$ if $(\mathrm{A})$ \\
\hline
\end{tabular}


Figure B2: Coefficient plot: teacher practices and correlation with student value added

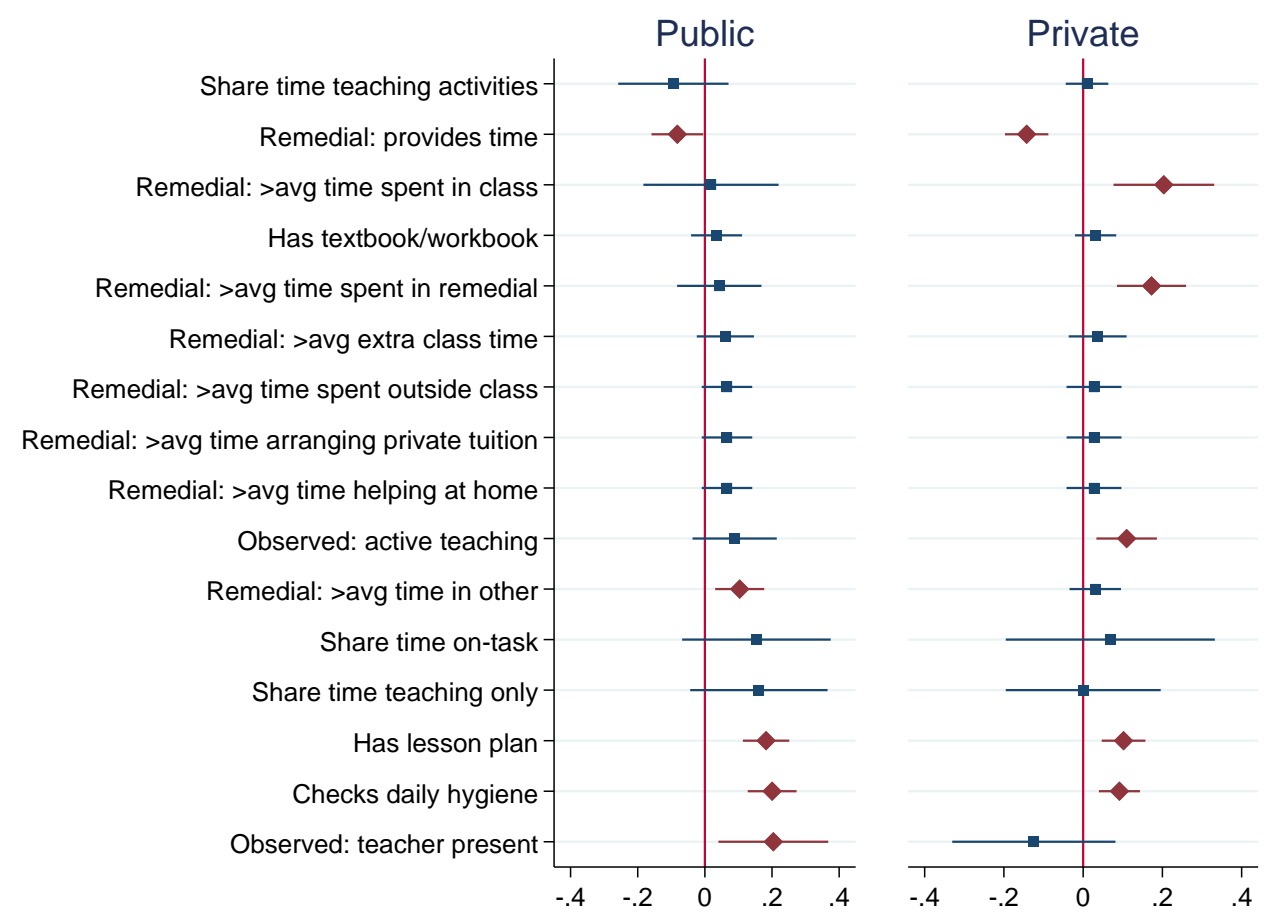

Note: This figure plots the coefficient of the simple relationship between each teaching practice and average student value added (SVA). SVA for each student is the residual from a regression of endline test score on baseline test scores for all years of available APSC data. The data is collapsed at the school-teacher-year level, such that each teacher is assigned an average of their students' value added for each year. The coefficients reported here are from a simple regression of each practice on student value added within each type of school (public on the left panel and private on the right panel), clustering standard errors at the school level. Statistically significant coefficients at the 90 percent level are marked in red diamonds, while coefficients that are not statistically significant are marked by blue squares.

sum of their row in the inverse variance-covariance matrix, thereby assigning greater weight to questions that carry more "new information". Figure B2 shows the correlation between each individual teacher practice we have in our survey and student value added. We included all practices in our index. 